
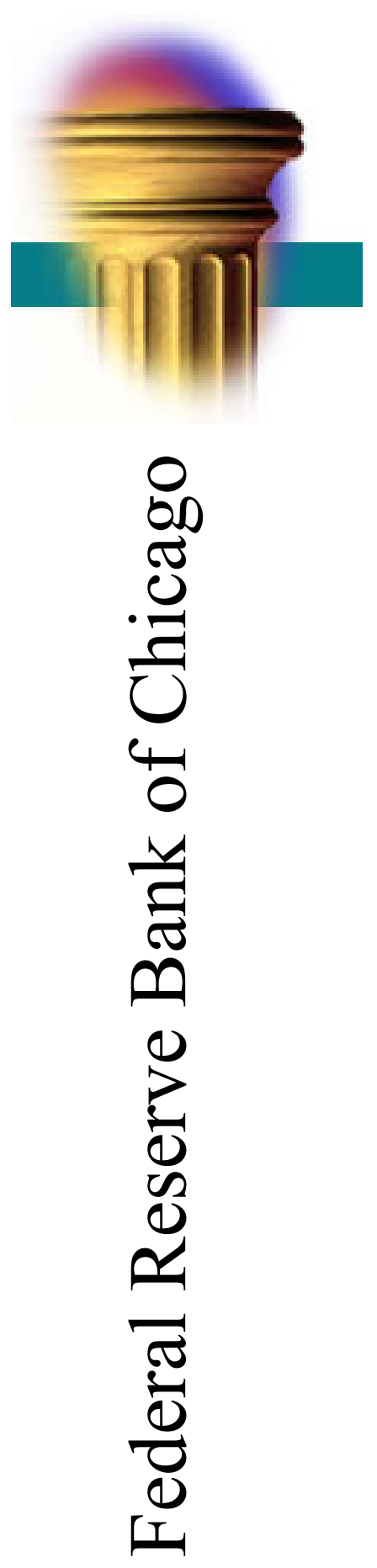

\title{
Effect of Ownership Composition on Property Prices and Rents: Evidence from Chinese Investment Boom in US Housing Markets
}

Jung Sakong

\author{
August 16, 2021
}

$$
\text { WP 2021-12 }
$$

https://doi.org/10.21033/wp-2021-12

${ }^{*}$ Working papers are not edited, and all opinions and errors are the responsibility of the author(s). The views expressed do not necessarily reflect the views of the Federal Reserve Bank of Chicago or the Federal Reserve System. 


\title{
Effect of Ownership Composition on Property Prices and Rents: Evidence from Chinese Investment Boom in US Housing Markets
}

\author{
Jung Sakong*
}

August 16, 2021

\begin{abstract}
A capital influx into local housing markets would be expected to increase house prices, but the spillover effect onto rental prices is theoretically ambiguous. I estimate both price impacts in U.S. residential housing markets using data from a boom in real estate purchases by buyers from China, which amounted to $\$ 200$ billion of purchases made between 2010 and 2019. Using a novel method to measure these purchases and an instrumental variable for where purchases are made, I find a large positive house price impact. Consistent with investment q-theory, rents fall as constructions rise, especially in areas with elastic housing supply.
\end{abstract}

*Federal Reserve Bank of Chicago (email: jung.sakong@chi.frb.org). These views are those of the author and do not reflect those of the Federal Reserve Bank of Chicago or the Federal Reserve System. I am extremely grateful to my committee chair Amir Sufi and members Marianne Bertrand, Raghuram Rajan and Luigi Zingales for their continuous guidance and support. I also thank Nate Anderson, Jane Dokko, Lancelot Henry de Frahan, Lars Hansen, Paymon Khorrami, Helen Koshy, Canice Prendergast, Vincent Reina, Alex Zentefis, as well as seminar participants at the University of Chicago Economic Dynamics Working Group, Finance Brownbag, PhD Conference on Real Estate and Housing at the Ohio State University, Federal Reserve Bank of Chicago finance seminar, Virtual Urban Economics Association Meeting and HKU joint Finance-Econ seminar. All errors are my own. 


\section{Introduction}

When there is an influx of capital into an asset market, what are the distributional consequences via asset and rental prices, and how do those consequences depend on asset supply elasticity? This question is particularly relevant in housing markets, in which households participate and so the distributional consequences can directly impact welfare. This paper explores this question with a special focus on the spillover effect of capital influx onto renters through rental prices: Renters - who make up about a third of households in the US - have lower income than owners on average, making them more vulnerable to changes in costs of living, but have received less attention in research.

In this paper I estimate the impact of capital influx on local housing markets in the context of the recent Chinese investment boom in US housing markets. This episode is an ideal laboratory for six reasons. First, the amount of purchases is large, estimated at around \$200 billion between 2010 and 2019 (Yun and Cororaton (2019)). Because housing markets are geographically segmented and much of the investment flowed disproportionately into certain markets - for example in Nevada and Florida - the local impact of the capital influx in those heavily targeted areas is likely to be even larger than is suggested by the total amount.

Second, the episode allows for measurement of this type of investor-owners and empirical identification of their impact on local markets, both of which are often difficult. The measurement relies heavily on the fact that there is a relatively small number of common surnames in China-about 100 surnames make up $85 \%$ of the population-and the empirical identification relies on the two common factors that are attractive to many buyers from China: travel time and pre-existing Chinese presence. The short time span and the large amount of inflow imply that the local impact will also be better measured. Third, many of these buyers purchased the US properties to rent out - i.e., as investment properties - as will be shown, and hence allows for the estimation of the supply-expansion force that has received less empirical attention despite its centrality in the classical q-theory of investment.

Fourth, unlike other waves of foreign investments, the buyers from China include many individual Chinese households who bought a single property. They are more similar to the majority of landlords in the US, and therefore the insights and estimates from this episode can be generalized to other housing-market contexts 11 Fifth, the capital inflow is potentially fragile: Many of the Chinese buyers had to bypass legal capital-control hurdles to purchase properties, and there is a possibility that stricter control enforcement may lead to a sudden reversal. Sixth, this episode is situated in the broader context of global imbalances, along with the roughly $\$ 1$ trillion of Treasuries held by Chinese individuals and institutions, which has been at the

\footnotetext{
${ }^{1}$ In 2015, 74\% of rental properties were held by individual investors ("mom-and-pop landlords") according to the Rental Housing Finance Survey. This number is down from $91.6 \%$ in 1991 (US Census Bureau (1996)).
} 
center of the savings-glut discussion.

The theoretical framework and empirical estimates from this paper extend to other contexts of capital influx into housing markets. First, international buyers often invest in residential housing markets in other countries. Other examples of high levels of real estate investment by purchasers outside the U.S. include Japanese buyers in US housing markets in the 1980s and Russian buyers in European housing markets in the past decade (Pristin (2005); Moss (2014)). Second, domestic institutional owners have been increasingly present in the rental housing market, even with single-family rental homes (Mills et al. (2019)). Third, debates over gentrification - in which residents with higher incomes move into areas of lower average wealth - have focused on entrants' role as residents and consumers, but entrants may also become investors and landlords in the areas they move into.

The paper starts with a simple model to understand the role of asset demand in the housing market. The model's key ingredients are both tenure choice and the choice over how much to spend on housing for households with different income levels operating in the same housing market, allowing for both rental and owner-occupation markets. In the model, ownership is a luxury - thus creating a sharp distinction between higher-income owners and lower-income renters - while housing expenditure exhibits close-tolinear Engel curve. I verify that these features are robust patterns in the Consumer Expenditure Survey (CEX) by instrumenting for permanent income using consumption. The model is otherwise a classical q-theory model of investment, with housing playing the role of capital.

In the model, foreign buyers apply lower discount rates to US housing, and they occupy only a fraction of what they buy. When foreign buyers enter a domestic housing market, the market-level house price and quantity both increase, and some domestic owners become renters themselves. Importantly, the impact on rents depends on parameter configurations. Whereas foreign buyers occupy some of the housing themselves and domestic owners switch to renting (forces that increase rents), higher asset demand spurs construction and existing homeowners reduce housing demand in response to a higher cost of living (forces that reduce rents). Especially if housing supply is elastic, rents decrease, improving welfare for renters with lower incomes.

Sorting out the net effect of these opposing forces on rents is ultimately an empirical question. I seek answers in the context of Chinese buyers in US residential housing markets. As a concentrated and identifiable episode, the recent wave of Chinese buyers is a promising setting to examine. The lessons drawn, however, are more broadly applicable to housing asset-demand booms in general.

The first empirical challenge is that no official measurement of this investment activity exists. Unlike foreign holdings of US Treasuries, there is no official statistic on US real estate holdings for China. The best 
estimates from the National Association of Realtors are based on self-reported surveys with a response rate of around $4 \%$.

I measure the extent of foreign direct investment in US real estate using deed records from CoreLogic ${ }^{2}$ I classify deeds as belonging to a Chinese owner if an individual owner has one of the 100 most common Chinese surnames. Using this method in sample counties covering $60 \%$ of the US population, I find that the fraction of US properties held by Chinese investors more than doubled in the period 2000-2015. The effect is highly heterogeneous.

Higher housing asset demand has implications for both house prices and rents and depend on local housing supply elasticities. Using zip-code-level data on housing market variables and the Saiz (2010) housing supply elasticity measure, I verify that correlations are consistent with my q-theory model. For instance, a percentage point increase in the share of housing in a given US zip code owned by residents of China is associated with $0.3 \%$ higher house price. When the Chinese share rises, rents rise if housing supply is inelastic, but fall if elastic.

To isolate the causal effect of Chinese asset demand on local prices of housing, I construct an instrument for Chinese buying activity using two factors that attract buyers from China: shorter flight time from China and the existing Chinese American presence. The instrument interacts the two. Identification comes from comparing zip codes with high pre-existing Chinese American presence as of 2000 against zip codes without that presence in the same metropolitan areas, before and after changes to flight times from China. Flight times are further predicted by starting with the 1997 network of domestic flights and in each year adding international flights from China in operation that year, then calculating the minimum hours to travel from China. This ensures that other changes that lead to domestic flight openings are not confounding the results.

Using the IV strategy, a percentage point increase in the Chinese-owned property share leads to a 5 percentage point increase in house prices. Estimating a precise impact on rent is difficult due to imperfect rent data, but on average, rents fall, with the effect concentrated in areas with elastic housing supply as measured by the Saiz supply elasticity (Saiz (2010)). The number of properties and building rates - as proxied using building permits - also rise. Lastly, owner-occupation rates fall by 0.4 percentage points, confirming that many of the Chinese buyers are buying to rent out.

Housing investments by foreign or domestic buyers with significant wealth are often reported in the popular press in a negative light $:^{3}$ The simple model in this paper offers a plausible reason. Buyers' entry

\footnotetext{
${ }^{2}$ While I focus on Chinese investors, the methodology extends to any foreign investors, as well as domestic out-of-town investors.

${ }^{3}$ Example headlines read "Soaring Vancouver home prices spur anger toward foreign buyers" (Gordon (2015) on Chinese buyers and "A \$60 Billion Housing Grab by Wall Street" (Mari (2020)) on institutional investors.
} 
can increase the aggregate utility by lowering rents, but welfare gains may be concentrated among a minority of renter-households if owner-households are the majority, as it is in the US. In response to rising house prices, many owner-occupants experience an increase in their cost of living.

This paper proceeds as follows. Section 1 lays out the model to understand the role of foreign buyers on renters and owners. Section 2 describes how I identify Chinese buyers and owners in housing data and presents the measured ownership shares. Section 3 turns to causal impact, first outlining the identification strategy and presenting empirical results on the causal impact of foreign buyers. Section 4 discusses the results and related literature.

\section{Model of Asset Demand in Housing Markets}

To clarify the forces at play, I construct a simple investment q-theory model with households who sort into owning and renting their homes. This section sets up the model, characterizes the steady-state equilibrium and contrasts it against the canonical q-theory framework, and finally makes predictions in response to an increase in demand by foreign buyers. In the current empirical setting, the "foreign buyers" in this model refer to Chinese buyers, but the model and its forces apply more broadly to other settings where outside capital enters a local housing market or where households' demand for housing as an investment vehicle changes.

\subsection{Model Set-up}

There are four types of agents in the model: households, foreign buyers, landlords, and builders. I first describe each in turn, starting with agents whose set-up depart from the canonical q-theory framework.

Households Households indexed by $i$ are endowed with heterogeneous income $Y_{i}$, distributed continuously with CDF $G\left(Y_{i}\right)$ and PDF $g\left(Y_{i}\right)$. The households solve a sequence of static problems: households choose whether to rent or own, housing $H$, and outside good $W$, to maximize

$$
\max _{\{\text {own,rent }\}, H_{i t}, W_{i t}} H_{i t}^{\theta \alpha} W_{i t}^{(1-\alpha)}
$$

where $\theta=1$ if rent and $\theta>1$ if own, subject to single-period budget constraints:

$$
W_{i t}= \begin{cases}P_{t+1} H_{i t}(1-\delta)+(1+r)\left(Y_{i}-P_{t} H_{i t}\right) & \text { if own } \\ (1+r)\left(Y_{i}-R_{t} H_{i t}\right) & \text { if rent }\end{cases}
$$


with endogenous house price series $\left\{P_{t}\right\}$ and rent series $\left\{R_{t}\right\}$, and exogenous interest rate $r$ and depreciation rate $\delta$. I consider parameter space in which some households own and some households rent (i.e. not exclusively one or the other).

The household set-up is static. The main loss from this simplification is the delayed dynamic response of households' housing stock, both within owners and also in the transition between tenure choices. Another potential loss is risk considerations, but risk is not the focus of the model in this paper.

Lemma 1 (Tenure sorting). There is a "marginal" household with income $\tilde{Y}_{t}$ that is indifferent between owning and renting. Households with income $Y_{i}>\tilde{Y}_{t}$ own, and households with income $Y_{i}<\tilde{Y}_{t}$ rent. The income level $\tilde{Y}_{t}$ around which households sort is given by the marginal household's indifference condition, and yields the following pricing equation:

$$
P_{t}=R_{t}^{\frac{1}{\theta}} \tilde{Y}_{t}^{\frac{\theta-1}{\theta}} e^{\frac{r}{\theta \alpha}}+P_{t+1} \frac{1-\delta}{1+r}
$$

where $\Upsilon \equiv[\theta \alpha \log (\theta \alpha)-(\theta \alpha+1-\alpha) \log (\theta \alpha+1-\alpha)]-[\alpha \log \alpha]$ with $\Upsilon<0$.

See the Appendix for the proof. With this set-up, ownership is a luxury, but conditional on the tenure decision, the housing expenditure has income elasticity of 1. From the Cobb-Douglas formulation and coefficients, the expenditure share spent on housing is higher for owners than for renters. The actual quantity of housing consumed may be higher or lower for owners than renters, depending on parameters and the two prices ${ }^{4}$

In this model, homeownership is a luxury while housing expenditure has a unit elasticity (as in the data when using permanent income to sort), because the set-up approximates a preference for wealth via $\theta$ (Straub (2018)). Micro-data evidence finds close-to-unit elasticity on housing relative to non-durable consumption (Piazzesi et al. (2007); Davis and Ortalo-Magné (2011); Aguiar and Hurst (2013); Berger et al. (2017)). Furthermore, in the Appendix, I use the Survey of Consumer Expenditure (CEX) data to show that the relationship between households' income levels and their tenure choice and housing expenditure data are consistent with the model here.

Foreign buyers Foreign buyers demand $F_{t}$ in asset quantity. Of these, they physically occupy or leave

\footnotetext{
${ }^{4}$ To understand the quantity when renting and owning, rearrange the indifference equation as:

$$
\theta \alpha \log \underbrace{\left(\frac{\tilde{Y}_{t}}{P_{t}-P_{t+1} \frac{1-\delta}{1+r}} \frac{\theta \alpha}{\theta \alpha+1-\alpha}\right)}_{=H_{\text {own }}\left(\tilde{Y}_{t}\right)}-\underbrace{(1-\alpha) \log (\theta \alpha+1-\alpha)}_{>0}=\alpha \log \underbrace{\left(\alpha \frac{\tilde{Y}_{t}}{R_{t}}\right)}_{=H_{\text {rent }}\left(\tilde{Y}_{t}\right)}
$$
}


vacant a fraction $\pi F_{t} 5^{5}$ Foreign buyers have a lower discount rate and therefore are willing to hold the acquired rental property in perpetuity and hence value each unit of real estate at:

$$
P_{t}^{F}=\frac{R_{t}}{1-\frac{1-\delta}{1+r^{F}}}
$$

where $r^{F}<r$. Foreign investors can have a lower discount rate for several reasons. First, they have higher average wealth and thus have a higher effective risk tolerance. Second, there can be a scarcity of investable domestic assets in China or in other foreign countries, which lowers the opportunity cost of capital for them (He et al. (2020)). Third, the house price movements in a US neighborhood are likely to be less correlated with foreign business cycles than that neighborhood's cycles.

Landlords Since the household problem only allowed housing for consumption, we need pass-through entities to be domestic real-estate investors (Kaplan et al. (2017); Greenwald et al. (2019)). Here, we assume away frictions between property types, and let landlords own to rent out with constant returns and without risk considerations. The other extreme is to let rental and owner-occupied properties be entirely segmented. Landlords are randomly matched to sellers, and if they run into a foreign buyer, they sell to the foreign buyer at the foreign buyers' willing-to-pay, i.e. the foreign buyers do not capture any of the surplus from trade. The recursion on price for the landlord's zero-profit condition implies:

$$
P_{t}=\frac{F_{t}}{K_{t}} P_{t}^{F}+\left(1-\frac{F_{t}}{K_{t}}\right)\left(R_{t}+\frac{1-\delta}{1+r} P_{t+1}\right)
$$

where $K_{t}$ denotes the total housing stock (i.e. in equilibrium $K_{t}=\int H_{t}+\pi F_{t}$ ). I use a different notation to signify that the households take the housing supply $K_{t}$ as given. This pricing equation translates asset demand into the average price. The timing is qualitatively unimportant, but leads to most consistent expressions for price ratios.

Builders Builders are as in the canonical q-theory models: they have a decreasing-returns-to-scale technology with which they can convert goods into buildings, with supply elasticity $\varepsilon$. The optimized investment follows:

$$
I_{t}=\kappa P_{t}^{\varepsilon}
$$

Markets The interest rates $r$ and $r^{F}$ and the incomes $\left\{Y_{i}\right\}$ are given exogenously. Endogenous house

\footnotetext{
${ }^{5}$ This contrasts with Favilukis and Van Nieuwerburgh (2017) who study the impact of out-of-town buyers and assume these buyers do not rent out their properties.
} 
prices $\left\{P_{t}\right\}$ and rents $\left\{R_{t}\right\}$ are determined to clear the asset and use markets for housing:

$$
\begin{gathered}
K_{t+1}=(1-\delta) K_{t}+I_{t+1} \\
\pi F_{t}+\int_{\underline{Y}}^{\tilde{Y}_{t}} \underbrace{\alpha \frac{Y_{i}}{R_{t}}}_{=H_{\mathrm{rent}, i t}} d G\left(Y_{i}\right)+\int_{\tilde{Y}_{t}}^{\bar{Y}} \underbrace{\frac{\theta \alpha}{\theta \alpha+1-\alpha} \frac{Y_{i}}{P_{t}-P_{t+1} \frac{1-\delta}{1+r}}}_{=H_{\mathrm{own}, i t}} d G\left(Y_{i}\right)=K_{t}
\end{gathered}
$$

where user demands by renters and owners have been plugged in using the household problem.

These five sets of equations determine the five sets of unknowns: $\left\{P_{t}, R_{t}, K_{t}, I_{t}, \tilde{Y}_{t}\right\}$.

\subsection{Steady State}

I first characterize the steady-state.

Definition 2 (Steady state). The following five equations characterize the steady state of this economy for $P, R, K, I$ and $\tilde{Y}$ :

$$
\begin{aligned}
\frac{P}{R} & =\frac{1+\frac{F}{K}\left(\frac{1}{1-\frac{1-\delta}{1+r^{F}}}-1\right)}{\left(1-\frac{1-\delta}{1+r}\right)+\frac{1-\delta}{1+r} \frac{F}{K}} \\
I & =\kappa P^{\varepsilon} \\
\delta K & =I \\
K & =\pi F+\frac{\alpha}{R} \int_{\underline{Y}}^{\tilde{Y}} Y_{i} d G\left(Y_{i}\right)+\frac{\theta \alpha}{\theta \alpha+1-\alpha} \frac{1}{P\left(1-\frac{1-\delta}{1+r}\right)} \int_{\tilde{Y}}^{\bar{Y}} Y_{i} d G\left(Y_{i}\right) \\
\tilde{Y} & =e^{-\frac{r}{\alpha(\theta-1)} P} P\left(1-\frac{1-\delta}{1+r}\right)\left(\frac{P\left(1-\frac{1-\delta}{1+r}\right)}{R}\right)^{\frac{1}{\theta-1}}
\end{aligned}
$$

The landlord arbitrage condition has been rearranged to express the price-rent ratio as a function of foreign share. The steady-state price-rent ratio is increasing and concave in the foreign share $\frac{F}{K}$ if and only if $r^{F}<r$. As $\frac{F}{K}$ ranges from 0 to $1, \frac{P}{R} \in\left[\frac{1}{1-\frac{1-\delta}{1+r}}, \frac{1}{1-\frac{1-\delta}{1+r^{F}}}\right]$.

Two steady states are illustrated in Figure 1, the dotted lines illustrate a steady state without foreign buyers, and the solid lines illustrate a steady state with foreign buyer demand. Figure 1a plots housingquantity demanded $H$ against income level $Y$ from the individual optimization problem. The break in the line indicates renter demand to the left and owner demand to the right. The next three figures illustrate the model equilibrium. The tenure cutoff is determined as in Figure 1c, with relative price (price-to-rent 
ratio) on the Y-axis and the fraction renting (with cutoff given as $\tilde{Y}$ ) on the X-axis: black lines indicate the marginal household's indifference condition, and the gray lines indicate relative-pricing based on tenure shares (Greenwald et al. (2019)). Figure $1 \mathrm{~b}$ illustrates the housing asset/investment market, with the housing supply curve in gray and the pricing equation from the net-present-value formula in black. Figure $1 \mathrm{~d}$ illustrates the housing use market, with the housing stock in gray and aggregated use demand (from renters, domestic owner-occupants and foreign residents) in black.

In the special case with $F_{t}=0 \forall t$ and $\theta=1$, these equations simplify to the neoclassical q-theory 6

\subsection{Impact of Additional Asset Demand}

To understand the long-term impact of an increase in foreign asset demand, consider the comparativestatic analysis with a higher $F$.

Assumption 3 (Assumptions on parameters). The income distribution $G(Y)$ has a lower bound at $\underline{Y}=0$, and is characterized by $g^{\prime}(Y) \leq 0$ everywhere. In addition,

$$
\alpha \leq \frac{(1+r) \delta}{r+\delta} \text { and } \theta \geq \frac{1-\alpha}{\alpha}
$$

There are four parts to this assumption. First, the income distribution is characterized by a (weakly) down-ward sloping density and hence a (weakly) concave CDF. This assumption is satisfied for exponential, Pareto and uniform distributions, for example. The second assumption puts an upper bound on the expenditure share of housing, and realistic calibrations fall easily within that bound.

The third assumption has the most bite. A high $\theta$ implies that there is a strong sorting force, such that small changes in relative prices do not lead to wild changes in tenure choices. In reality, tenure sorting by income level arises from multiple mechanisms that are un-modeled here, including financing constraints. The high $\theta$ could be rationalized on the grounds that it is a reduced-form way of capturing these multiple mechanisms that lead to the tenure sorting, which is a robust feature of the data.

The third assumption is consistent with the CEX data. Using the CEX data and the estimation specified in column (7) in Appendix Table 4, I get estimates of $\hat{\alpha} \approx 0.38$ and $\hat{\theta} \approx 7.35$, which satisfy the third assumption.

Proposition 4 (Comparative static in $F$ ). In a steady-state equilibrium with a higher $F: K, I$ and $P$ are higher, $\frac{F}{K}$ is higher, and $\frac{P}{R}$ is higher. The relative level of $R$ depends on the parameter configuration.

\footnotetext{
${ }^{6}$ The steady-state rent under this special case is $R=\left(\frac{\delta \alpha(\Sigma Y)}{\kappa}\right)^{\frac{1}{\varepsilon+1}}\left(1-\frac{1-\delta}{1+r}\right)^{\frac{\varepsilon}{\varepsilon+1}}$ and $P=\left(\frac{\delta \alpha(\Sigma Y)}{\kappa\left(1-\frac{1-\delta}{1+r}\right)}\right)^{\frac{1}{\varepsilon+1}}$
} 
See the Appendix for the proof.

The crux of the model is to understand the various spillover effects of foreign buyers' asset demand on the rental market. In this partial-equilibrium model, the spillover effect onto the renter population is largely summarized by what happens to rents, thereby affecting the real income of lower-income renters. To spell out the four forces at play, I differentiate the user-market equation in $F$ and rearrange in terms of $\frac{d \log R}{d F}$ :

$$
\begin{aligned}
\Lambda \frac{d \log R}{d F}= & \pi+\frac{d \tilde{Y}}{d F} \tilde{Y} g(\tilde{Y}) \frac{\alpha}{R}-\varepsilon K \frac{d \log P}{d F} \\
& -\frac{\frac{\theta \alpha}{\theta \alpha+1-\alpha}}{P\left(1-\frac{1-\delta}{1+r}\right)}\left[\frac{d \log P}{d F} \int_{\tilde{Y}}^{\bar{Y}} Y_{i} d G\left(Y_{i}\right)+\frac{d \tilde{Y}}{d F} \tilde{Y} g(\tilde{Y})\right]
\end{aligned}
$$

where $\Lambda \equiv \frac{\alpha}{R} \int_{\underline{Y}}^{\tilde{Y}} Y_{i} d G\left(Y_{i}\right)>0$.

First, the foreign buyers have some usage demand (i.e. a fraction $\pi$ of them buy the housing as primary residence or vacation home). Second, there are more renters and average renter income goes up. Third, the asset demand spurs investment and there is more housing supply - this is the main neoclassical q-theory force and is stronger for higher supply elasticity $\varepsilon$. Fourth, there are fewer owners (extensive margin), and owners who stay owners also demand less housing (intensive margin) because the cost of housing has gone up. The last two forces will take more time to manifest. Of these four, the first two forces raise rent, while the last two lower it, making the net effect ambiguous.

Given the partial-equilibrium nature, there are missing forces. For example, higher house price may lead existing homeowners to spend more due to a wealth effect. This increases income, for those working in the local non-tradable sector (Mian and Sufi (2014)), raising the level of $y_{i}$ in the rental demand equation.

The dynamics of the impact are shown for a calibrated example in Figure 2. The first three figures plot the following model quantities against time: housing stock (Figure 2a), house price per unit of housing (Figure 2b), and the fraction of domestic households that rent (Figure 2c).

In addition to rent, user cost also changes. User cost for owners (or flow benefit) is defined as $P_{t}-$ $\frac{1-\delta}{1+r} P_{t+1}$ in period $t$ (required return plus depreciation minus capital gain). The domestic residents' average user-cost is defined as the quantity-weighted average of the user costs:

$$
\int \text { user cost }_{i t} \frac{H_{i t}}{\int H_{i t}}=\frac{\alpha\left(\int_{\underline{Y}}^{\tilde{Y}_{t}} Y_{i} d G\left(Y_{i}\right)\right)+\frac{\theta \alpha}{\theta \alpha+1-\alpha}\left(\int_{\tilde{Y}_{t}}^{\bar{Y}} Y_{i} d G\left(Y_{i}\right)\right)}{K_{t}-\pi F_{t}}
$$

which is affected by three things: total supply $K_{t}$, foreign buyers' residential demand $\pi F_{t}$, and the tenure shares $\tilde{Y}_{t}$. With $\pi=0$, user cost is unambiguously lower under Proposition 4 Rent, owners' user cost and 
the average user cost for the same calibrated example are plotted in Figure $2 \mathrm{~d}$.

Importantly, rent adjusts to the new steady-state value immediately. This is in contrast with the slow adjustment of the average user cost as well as the adjustment of rent in a classical q-theory framework, in which rent adjusts only as supply expands. In this model, owner-occupied homes are quickly converted to rental units, allowing for the rent to adjust immediately. This quick adjustment will be found in the empirical analysis of Chinese buyers in the empirical section later.

\subsection{Mean and Median Welfare}

How does the foreign buyers' housing-market impact translate into welfare impact for domestic households over the income distribution? Given the stylized model in this paper, the welfare discussions are suggestive but not comprehensive. In particular, much of the welfare impact on owners who remain owners depends on the welfare impact of housing-wealth shock more generally (Berger et al. (2017)). In particular, the model abstracts away from collateral constraints, which make housing-wealth shocks more welfareimproving for homeowners by relaxing the constraints (Mian and Sufi (2011); Kaplan and Violante (2014)). This is an important caveat and will be discussed more in detail below.

Proposition 5 (Steady-state welfare gradient). In the new steady state with foreign buyers relative to the one without, the welfare difference is weakly decreasing in the income level.

See the Appendix for the proof. The result is intuitive given that price-to-rent ratio is higher in the new steady state per Proposition 4. For an illustration, see the solid black line in Figure 2e. The shape is also intuitive: the switchers' welfare change is lower than that of original renters, because the welfare loss from choosing renting over owning is increasing in income level, but by revealed preference, their welfare change is higher than owners who stay owners.

The overall welfare impact of foreign-buyer entry is a combination of this long-term impact and the initial impact of the price increase, which delivers a positive wealth shock to those who own housing. In decomposing housing wealth shocks, this has been called the endowment effect (Berger et al. (2017)). The net present value (NPV) that combines the impact of the positive endowment effect and the ongoing higher cost of living determines the overall welfare impact.

A numerical example of the NPV welfare impact - in an example calibration with rent decrease - is shown in Figure 2e. The small red dots indicate the initial news shock that delivers positive endowment effect on owners, expressed as the ratio of the new utility over an economy that did not see foreign-buyer entry, plotted against the income of a domestic household. The black dashed and solid lines are the relative 
welfare at $t=1$ (event time) and the new steady state. The black circles indicate the overall NPV ratio. It shows that the household with the highest welfare gain is the marginal owner in the original economy, who received the endowment shock and did not mind renting too much. This last implication applies more broadly in the model.

In the static model here, the gain from the price jump is consumed, rather than spread out over multiple periods. This is a possible limitation of the static modeling of the household problem. Nonetheless, the broader insight that the endowment effect is dominated by the price rise (e.g. income effect) for owners is robust, as long as $\delta>0$ (Berger et al. (2017)). The price gain applies to the current housing stock owned, but that stock depreciates over time and hence cannot guarantee the same amounting of housing over time. To make up for depreciation, the payments are now more expensive. The key is that depreciation or homeowners' cost of maintenance scales with price $P$. This may be due to several reasons: One example is homeowner association (HOA) fee, which tends to be higher when an area becomes more expensive; another is property tax, which scales with the property value albeit with lags and caps in the short run.

To illustrate with a stark example, take a sufficiently high-income household who was a homeowner and stays a homeowner. Nothing changes, except they now pay higher HOA fees and property taxes. They could sell the house to rent or move out, capturing the gain. That choice is modeled in, but it is not taken. Ownership has gains that are a luxury, so such a high-income household bears a larger cost to sell and capture the price gain. For example, there may be a preference to be in an exclusive suburb, which would be too costly to give up on for high-income households. The $\theta$ in the model captures this and other forces that make giving up homeownership costly, especially for higher-income households.

Given this cross-sectional welfare impact, it is possible to contrast the mean welfare impact against the median impact, presented as the time series of flow utility ratio against no-foreign-buyer economy in Figure 2f. In this numerical example, the average cost of housing decreases driven by the large rent decrease (Figure 2d) so the aggregate welfare is higher with the foreign-buyer demand. Yet, because homeowners are the majority of the population, the median welfare is lower due to the higher cost of living for homeowners.

More broadly, welfare gains are concentrated among the minority renters, so even despite the aggregate welfare gain, median voter theorem implies political or social response to the foreign-buyer shock would be negative. For the starkest example, take the case when $\pi=0$, under which the average user cost definitely goes down; as long as $\tilde{Y}_{0}<0.5$ and $\tilde{Y}_{1}<0.5$, the median person (either by income or by welfare impact) will oppose. The negative response would be more pronounced if voice or influence were increasing in income. The divergence between mean and median welfare is not the case in many dense cities (e.g. Chicago at $45 \%$ homeownership), but those areas often have a low elasticity of housing supply, so the welfare gain itself 
might be small or negative.

The income-gradient of welfare impact analyzed here is limited: With credit constraints, the rise in house prices can be welfare-enhancing for constrained homeowners (Mian and Sufi (2011); Kaplan and Violante (2014); Berger et al. (2017)). 7 More broadly, the literature on housing wealth has identified many ways in which a rise in house price can increase - rather than decrease - real income. Some of them are modeled here, most notably the ability to sell the house to capitalize on the capital gain while moving to the rental option. If homeowners were credit constrained, the higher house price, while raising the cost of living, can still raise welfare by relaxing collateral constraints. Such welfare gain among homeowners could counteract some of the implications discussed here. Nonetheless, the welfare consequence still holds for homeowners who own only their primary residence, has sufficient liquidity buffer and has a strong preference for owneroccupied housing.

The welfare impact is testable with survey elicitation of reactions to foreign buyers, institutional investors and incoming residents in gentrifying neighborhoods, which can then be correlated with income, tenure and liquidity-constraint proxies.

\section{Measuring Ownership of US Housing by Residents of China}

I study the empirical impact of buyer entry on local housing markets in the concentrated episode of Chinese foreign buyer entry in 2010-2019. Given the large magnitude - estimated at roughly $\$ 200$ billion of residential purchases in a decade - the episode is of independent interest as well. I begin by proposing a methodology to measure Chinese ownership in US housing.

\subsection{Data and Measurement}

Information on foreign direct holdings of US real estate is not readily available. I construct zip-codelevel panel data on Chinese holdings of real estate properties using deed records from CoreLogic. I use last names on deed records as the main search criterion to identify Chinese owners and buyers.

"Chinese buyers" can encompass many types of buyers. I begin the measurement exercise by conceptually defining the type of buyers I want to capture. Most importantly, they are not local residents, and in particular they purchase properties using wealth from abroad. It also matters that the buyers have a higher

\footnotetext{
${ }^{7}$ Many empirical studies focus on the impact of house-price increase on consumption. However, consumption response to housing wealth shock is not equivalent to the welfare impact. Under a Cobb-Douglas aggregator between housing and non-durable consumption for example, consumption remains unchanged even if house price rises and welfare falls. If there are in addition some constrained households who then increase consumption, it is possible to have consumption go up but average welfare still go down among homeowners.
} 
willingness-to-pay via a higher effective discount factor.$^{8}$ The property purchased could be used for multiple purposes, e.g., as primary residence for a family member (for example, properties bought by parents residing in China for their children residing temporarily in the US to attend college), as vacation home to be left vacant when not in use, and as an investment home to be rented out. The key delineation is the source of capital, and the various restrictions on buyer names below will be imperfect ways to get at this class of buyers.

The 100 most popular Chinese surnames account for $85 \%$ of China's population $]^{9}$ See Online Appendix Table A.1 for the list of the 100 surnames in 2007, with the Mandarin Pinyin romanization. I use four common romanization schemes under two dialects to identify Chinese last names: Pinyin and Wade for Mandarin, and Jyutping and Hong Kong Government Cantonese Romanisation (HK) for Cantonese. For example, for the third most common last name, the possible romanizations are Zhang (Pinyin), Chang (Wade), Zoeng (Jyutping) and Cheung (HK). Other romanizations (e.g. Cheong and Chong) are excluded. If any of the individual owners of a property has one of the 100 last names, I classify that property as belonging to a Chinese buyer. In the 2012-2013 assessor cross-section of the CoreLogic deed records, the actual frequency of the 100 last names is ranked in Online Appendix Figure A.5 against the frequency rank in China's population as of 2007. The downside of this measure is that it also captures Chinese Americans (roughly $1 \%$ of the US population) and non-Chinese last names with the same alphabetization (e.g. Long).

To exclude both Chinese Americans and non-Chinese individuals with the same surname alphabetization, I exclude individual buyers with non-Chinese first names. Information on origin of first names comes from a website "Behind the Name: The etymology and history of first names" (https://www.behindthename.com/). For example, searching for the Chinese romanization of my first name ("Zheng") shows that the name is Chinese, while searching for my unofficial English name ("Max") shows that the name is German, English, Swedish, Norwegian, Danish or Dutch. In all of the measures of Chinese buyers, I exclude buyers with first names that are identifiably non-Chinese.

I construct two main measures of Chinese buyers. The "broad measure" includes all individual and institutional buyers with a Chinese surname, and without a non-Chinese first name. Given these restrictions, most institutional buyers I include are trusts. The "narrow measure" further imposes that there are no loans on the deed record, as Chinese buyers disproportionately engage in all-cash transactions ( $71 \%$ of transactions according to Yun et al. (2017)). Lastly, for comparison I separately measure buyers with Chinese surnames

\footnotetext{
${ }^{8}$ As mentioned above, Chinese buyers likely have higher average wealth, have limited domestic investment opportunities due to political risk, and have consumption process less correlated with the US geographies they enter.

${ }^{9}$ LaFraniere, Sharon. "Name not on our list? Change it, China says." The New York Times. April 20, 2009. As the article points out, Chinese word for "the people" is băi xìng. Translated literally, it means "hundred surnames." Top 100 surnames account for only $16.4 \%$ of the population in the US by contrast (Word et al.(2008)).
} 
and English first names as a rough proxy for Chinese American buyers. For each of these measures, the main specification of the variable is defined as

$$
\text { share } \equiv \frac{1}{0.85} \frac{\# \text { of units held by } \text { group }_{z t}}{\text { total \# of units } z}
$$

for zip code $z$ in year $t$. I used the 100 most popular Chinese surnames to identify Chinese owners. Since those surnames account for roughly $85 \%$ of the Chinese population in China, I scale up the measured Chinese share by $\frac{1}{0.85}$. I also use alternative specifications where I use total square footage or total number of bedrooms instead of number of units.

As for the sample of housing data, I use CoreLogic deed and tax records from 1,116 jurisdictions covering the counties shown in Online Appendix Figure A.3, to have a consistent and comprehensive coverage for 2000-2015. Those counties cover roughly $60 \%$ of the US population.

If I am solely interested in measuring Chinese international buying activity, the current methodology omits large institutional owners. For example, "Chinese life insurance firms like Anbang have been big buyers in New York.'10

\subsection{Measured Chinese Buying Activity}

The measured Chinese-owned property counts and shares are shown in Figure 3 . Figure 3 a plots monthly gross purchases by Chinese buyers, using the narrow measure that further imposes all-cash financing. The blue solid line represents the number of transactions while the red dotted line represents total values in these transactions with magnitudes on the right axis. By both measures, purchases by Chinese buyers jumps around 2009 and continues to increase to around 2013. Even though the methodology is conservative and hence the plotted quantities are on the lower side, the magnitudes are large. Thousands of purchases were made accounting for around 1 billion USD each month during the active years following 2009.

For assessing the impact of such demand on US housing markets, we care about net ownership as a proxy for the net demand for housing assets, accounting for sales and also for the size relative to the underlying housing markets. For that purpose, figures $3 \mathrm{~b}$ and $3 \mathrm{c}$ plot the share of total residential properties owned by those with the top 100 most populous Chinese surnames and without English first names, scaled by 0.85 . Relative to the gross flow quantities in figure 3a, figures $3 \mathrm{~b}$ and $3 \mathrm{c}$ represent net stock measures.

Figure $3 \mathrm{~b}$ is for the same narrow measure that further imposes all-cash financing, and exhibits the same kinked increase starting around 2009. Figure $3 \mathrm{c}$ is for the broad measure that does not impose an absence

\footnotetext{
${ }^{10}$ Rapoza, Kenneth. "Why Washington is making it easier for rich foreigners to buy US real estate.” Forbes. February 3, 2016.
} 
of mortgage: It is larger in magnitude than the narrow measure but lacks the sharp increase in 2009, instead increasing smoothly throughout the period.

For visualizing purchase trends, the broad measure is inferior, as it may include transactions by Chinese Americans, for example. However, for the IV estimation in this paper, the broad measure is superior. With a broad measure, the instrument can capture only the meaningful variation due to actual Chinese buyers that is more likely to be included fully in the broad measure. By contrast, if the observed Chinese owners are a fraction of the actual ownership activity, then the unobserved component will be correlated with the instrument, and hence lead to overestimates in the second-stage regression assessing the impact of Chinese owners on local housing markets.

The average characteristics of the properties owned by Chinese owners by the broad measure are reported in Table 1, for the years 2009-2014. Compared to all properties in the sample of counties, properties purchased by Chinese buyers are more expensive and have more bedrooms, but have fewer square feet. The majority of the purchases are for single-family homes at $68 \%$, comparable to the overall average. Relative to the average, Chinese buyers buy disproportionately more condominiums at $15 \%$ of total purchases, relative to $7 \%$ for overall purchases. The deed records provide one method of approximating owner-occupation or absentee ownership, by comparing the property address to the mailing address to which the owner decides to mail the deed (often the residential address for domestic buyers). For Chinese buyers, this is not the most reliable information for owner-occupation, since foreign investors - those that do not plan to live in the properties - often use the property address as their mailing address for the deed.

The second panel of Table 1 compares the zip-code characteristics of where Chinese buyers enter against all zip codes in the sample counties. These zip codes have higher house price, rent and incomes, in more urban areas with lower housing supply elasticity. Relevant to the instrumentation strategy to be introduced later, these zip codes have higher pre-existing Chinese population (5\% in 2000) and have flight routes from Chinese that are more than an hour shorter on average. They are disproportionately more likely to be in the West Census region, and less in Midwest and South.

There is much geographical heterogeneity in the Chinese buying activity. Online Appendix Figures A.4a and A.4b plot the broad and narrow measures, respectively, across the US. Some areas saw more dramatic increases in Chinese ownership share 11

\footnotetext{
${ }^{11}$ In the state of Nevada (mostly Las Vegas and Reno in my sample), the fraction owned by the 100 surnames went from $0.2 \%$ in 1998 to $2 \%$ in 2013, a tenfold increase. In a couple of zip codes in the outskirts of Las Vegas (89139 and 89148), the share went from $0.2 \%$ and $0.3 \%$ in 1998 to $9.3 \%$ and $8.3 \%$ in 2013 . Several commentators of the 2000 s housing boom have pointed out that several cities with elastic housing supply also experienced large price boom and bust. In particular, Nathanson and Zwick (2017) point to "anomalous cities" in "Arizona, Nevada, Florida, and inland California." Those four states experienced 13th, first, 22nd and second highest rates of growth in Chinese share among the 50 states.
} 


\subsection{Validation of Chinese Buyer Measures}

Given that there is no separate data set tracking buyers of US real estate who reside in China, validating my measures is difficult. One approach is to compare actual holdings against information on potential buyers' interest in US places. To this end, I obtain a list of properties listed on Juwai.com. According to the Wikipedia entry, Juwai.com is "China's largest international property website for Chinese buyers of overseas property... Juwai attracts 1.5 million unique visitors a month and 'is usually the first place China's newly rich begin their [international property] search." If the intensity of listings on Juwai.com represents Chinese buyers' interest in an area in the US, then I should find those areas also have higher holdings by Chinese owners.

One major downside of this exercise is that the Juwai.com listings were obtained in February 2017, while the most recent real estate holdings information is in 2013. Therefore, correlations between listing frequency and shares held will be low due to the timing mismatch. The correlations would also be lower to the extent that listing frequency is an imperfect measure of Chinese buyers' interest, and to the extent that Chinese buyers' interest does not translate to actual holdings.

Online Appendix Figure A.6a shows the geographical distribution of the ratio of number of properties listed on Juwai.com in February 2017 to total number of properties in that zip code in 2013. Online Appendix Figure A.6b plots the cross-sectional correlation between the Juwai.com listing intensity measure defined above (for February 2017) with the Chinese share of properties owned in each of the year $t$, using the narrow measure of ownership share. Two things are worth pointing out. First, the level of correlation is quite low but positive. That is, Chinese owners hold bigger fraction of properties in zip codes that have more properties listed on Juwai.com in 2017. Second, and more importantly, the correlation is rising over time, and is twice as high in the intensive Chinese investment years of 2009-2013 as it is in earlier years.

\section{Housing Market Impact}

Using the estimated Chinese buying activity from the previous section, I estimate the impact of the buyers on local housing markets. I begin by decribing the data sources for various housing-market outcomes - house price index, rent index, building rate and owner-occupation rate - followed by simple difference-indifference correlations with the Chinese-ownership numbers. To get at the causal impact of Chinese demand on these housing-market outcomes, I propose an instrumentation strategy based on the known pull factors for Chinese buyers: flight time from China and pre-existing Chinese American presence. 


\subsection{Housing Market Data and Correlations}

Housing market data are at an annual frequency for 2000-2015, and the unit of observation is a zip code when data are available or county otherwise. Such narrow geographically aggregated or averaged data are appropriate for measuring the equilibrium impact of foreign buyers on local housing markets. The main housing-market data of interest are house prices, rents, investment or building rate and homeownership rates, corresponding to the key quantities in my q-theory model. The most relevant for household welfare are the two prices: house prices and rents.

House price data come from the Zillow Home Value Index and the CoreLogic repeat sales index. The CoreLogic index is widely used and is constructed using a more straightforward repeat-sales methodology, but its cross-sectional coverage is lower, with data for about 7,000 zip codes. The Zillow Home Value Index uses Zillow's proprietary methodology that combines repeat-sales and hedonic methodologies, and is available for roughly 29,000 zip codes, covering most of zip codes in the US. The two are highly correlated: In the 2000-2015 annual panel, the two have a correlation of 0.56 in logs. When zip-code and year fixed effects are included to focus on diff-in-diff variations, the correlation implied by the within $R^{2}$ rises to 0.82. Given the high correlation between the two data series and the broader coverage of the Zillow Index, the main analysis uses the Zillow Home Value Index for house prices, and I report replications with the CoreLogic Index in the Online Appendix.

Long panel data for rent indices are not available at the zip-code level for the study period 2000-2015. I use two rent dices, each with limited coverage. Zillow Rent Index has zip-code level data, but only start in 2010. I also use median rents for 3-bedroom units from the US Department of Housing and Urban Development (HUD)'s Office of Policy Development and Research website; these data span the study period, but are available at the county level. HUD's median rents are derived from the Census and American Community Survey (ACS). Overall, these two data series have a panel correlation of 0.81 , but once zip-code and year fixed effects are included, the diff-in-diff variations are not correlated. Because of this low diff-in-diff correlation between the two series, the data imperfections of both series and the more theoretically ambiguous impact on rents, I report results using both data series in the main analysis.

Homeowner and renter shares come from the ACS at the county level. Building rate is obtained from the Building Permits Survey, by mapping the FIPS place counts to corresponding counties.

I report the relationship between these housing-market variables and the measured Chinese ownership shares in the bottom panel of Table 3 . County fixed effects and year fixed effects are included because there are clear time-invariant cross-sectional difference in zip codes (e.g. high Chinese presence and prices in 
California) as well as aggregate trends.

The housing estimate suggests that a percentage point increase in shares of properties held by Chinese is associated with a $0.34 \%$ increase in house prices. The average correlation with rent is positive, but splitting the zip codes up by housing supply elasticity shows that more Chinese holdings is associated with lower rent in areas with elastic supply, and with higher rent in areas with inelastic supply. These correlations are consistent with the theoretical framework laid out above.

There are many reasons to be cautious in interpreting these correlations as causal impact of Chinese buyers on local housing markets. First, the Chinese shares are measured with much measurement error, which would bias all estimates toward zero. Second, Chinese buyers do not randomly choose where they buy properties but make a calculated and endogenous decision. These concerns motivate the use of predictors of Chinese buying activity in order to isolate the causal impact of Chinese buyers on local housing markets.

\subsection{Instrument for Chinese Asset Demand}

To establish a causal link from foreign asset demand to local housing markets, I propose an instrument based on factors that draw Chinese buyers but are otherwise unlikely to affect the local housing markets. The instrument interacts changes in travel times to US areas from China (driven by changes in direct flight routes) with zip codes within those areas that have higher pre-existing Chinese American presence and are therefore potentially more appealing to buyers from China. Flight-time changes vary mostly at the airport level, which again varies mostly at the metropolitan-area level. For zip codes in a given metropolitan area, the instrument can be viewed as a difference-in-difference variable, comparing local outcome before and after flight-time changes, between high- and low-Chinese presence zip codes. I first describe each factor in some detail and then propose the interacted instrument.

Chinese buyers value ease of access from China (Rosen et al. (2017); Yun et al. (2017)) 12 Unlike financial assets, real estate properties are heterogeneous, and hence pose an entry barrier to outsiders without knowledge of the local housing market. This segmentation is larger for Chinese investors who must cross the Pacific 13 When it becomes easier to fly to an area, either by having a direct flight, by making fewer layovers or by flying fewer hours, it should lower Chinese investors' cost of acquiring information about a local housing market, and hence induce higher investment demand. Such a lower cost of access can be manifested in several tangible ways for Chinese buyers. First, buyers who wish to own and rent out their property can perform maintenance more easily. Second, for buyers of vacation homes, lower travel time

\footnotetext{
${ }^{12}$ Flight time also matters for business ownership globally (Campante and Yanagizawa-Drott $(2018)$ )

${ }^{13}$ Foreign investors do hire local agents (HG.org). Higher information asymmetry still implies lower bargaining power in the principal-agent problem between the foreign investor and her intermediary.
} 
makes it easier to get there for vacations. Third, easier travel stimulates more information flow in general, so buyers in China are more likely to learn about that area.

To measure the shortest travel time from China to various US locations, I use data on flight routes and airport locations. Flight route data come from Department of Transportation's Bureau of Transportation Statistics T-100 Segment (All Carriers). The data contain origin-destination route information by airline and plane type. I only use passenger routes flown by planes with jet engines (e.g. Boeing 747 and 777). Airport location data come from Federal Aviation Administration's Address of Public Use Airports.

Flight time from China can change when direct flights from China change or domestic layovers change. The latter raises additional endogeneity concerns: More flights would open up to areas in the US attracting more businesses, for example. To address this concern, I use historical domestic route network and route changes that result from direct flight openings to a different city.

To be robust to the concern that flight changes may anticipate local economic conditions, I construct the travel time instrument in the following way. I first take the domestic flight route network from 1997, the earliest year for which I have data from the T-100 Segment data. Then, for each year, I add direct routes in operation from any airport in mainland China to the network of 1997 domestic flights. For this network of flights, I assume flights travel at 500 miles per hour, while layovers (i.e. passing through a node) take three hours. To this network of flights, I add straight-line driving legs from each airport to the centroid of each zip code. Driving legs are assumed to have distance equal to the straight-line distance between the airport and the zip code centroid, calculated using the Haversine formula. I assume that all driving is done at 60 miles per hour. Given this network, I calculate minimum time to each zip code centroid from anywhere in China, year by year.

There were several direct-flight changes in the time period of the study. To list a few prominent examples, direct-flight openings include those from China to Chicago (2001), New York City (2003), Newark (2006), Washington DC (2007), Atlanta (2008), Seattle (2009), Detroit (2010) and Honolulu (2012); directflight closings include those from China to Detroit (2002) and Atlanta (2010). The frequency of direct-flight changes generates many time series events, adding to the power of the empirical methodology. Note that I do not include flight routes from airports in Hong Kong, Taiwan, Korea or Japan. Flights to Los Angeles, CA and San Francisco, CA are in operation and do not change throughout sample period.

To illustrate the variations induced by the predicted flight time, Online Appendix Figure A.8a shows the areas affected by direct flight opening to O'Hare International Airport in Chicago, IL, as an example. The light blue areas ("open direct flight") are affected areas in the Chicago metropolitan area, and the light purple areas ("direct flight for some yrs") are the list of cities above where at some point there were direct 
flights from China. The green areas ("decrease travel time") experienced a reduction in travel time from China. In the yellow areas ("no change") where minimal travel time was uanffected by direct flight opening to Chicago, IL. Online Appendix Figure A.8b shows an analogous map for 2010, when there was a direct route opening to Detroit, MI but a route closing to Atlanta, GA.

The other factor that draws Chinese buyers is the presence of existing Chinese population (Yun et al. (2017)). Existing Chinese population may predict higher likelihood of Chinese purchases through multiple channels. First, existing Chinese communities will have local amenities such as restaurants and grocery stores that better suit Chinese buyers. Second, for those considering residence, buyers can find neighbors who share more common language and culture. Third, the same factors that drew the existing Chinese residents may also be attractive to incoming buyers.

In order to proxy for existing Chinese residents, I use Chinese population shares by zip code from the 2000 Census. The main specification uses a binary for having a high Chinese presence in 2000, with $1 \%$ population share as the cutoff point. $15 \%$ of population resides in zip codes in this category. For robustness, I also use the Chinese population share itself ${ }^{14}$

My identification strategy exploits the interaction of these two sources of variation, by comparing zip codes with high pre-existing Chinese presence to those without, before and after changes in predicted flight time from China.

\subsection{Specification and First Stage}

The actual instrument interacts the changes in travel time (actual or predicted) with a time-invariant zipcode-level pre-existing Chinese presence measure. The first stage estimates are presented in Table 2, For US zip code $z$ in Core-Based Statistical Area (CBSA) $m$ in year $t$, the main specification in column (3) is

$$
\text { Chinese share }_{z m t}=\gamma_{0}[\text { Hours }]_{z m t}+\gamma_{1}[\text { Hours }]_{z m t} \times[\text { Has Chinese presence }]_{z}+\delta_{z}+\delta_{m t}+\eta_{z m t}
$$

Column (1) is a simple cross-sectional relationship between Chinese ownership shares and flight time from China (predicted using the 1997 domestic layout). Areas with shorter flight time as measured by lower hours have higher Chinese ownership share. In a simpler difference-in-difference regression in column

\footnotetext{
${ }^{14}$ A previous version of this paper interacted direct-flight changes with whether the zip code has the number 4 , to predict Chinese buyer demand. In China and East Asia, the number " 4 " is considered unlucky because it is homophonous with the character for death (sì for four and š̌ for death in pinyin romanization). Such tetraphobia may spill over into Chinese buyers' taste for housing assets. In Vancouver, for instance, "houses with address number ending in '4' are sold at a 2.2\% discount" (Fortin et al. (2014)). Its predictive power derived from the correlation with existing Chinese presence. In a cross-section zip codes with the number 4 in the last three digits of the zip code have lower Chinese American population shares (Online Appendix Figure A.9.
} 
(2) with hours and pre-existing Chinese presence, with year and zip code fixed effects, we see that when predicted hours fall, Chinese shares rise more in areas with higher pre-existing Chinese shares.

The main specification in column (3) replaces year fixed effects with year $\times$ CBSA fixed effects. This fully controls for CBSA-level confounding factors. Housing market returns, for example, have a significant geographic factor structure (Piazzesi and Schneider (2016)). These fixed effects absorb much of the variation in hours itself, although not completely since airports and CBSA's overlap incompletely. Column (4) omits hours as a predictor.

Column (5) replaces the binary for high Chinese presence in 2000 with the Chinese population share in 2000 itself. Column (6) replaces the predicted travel time from China with the actual travel time. The results barely change.

Column (7) uses the narrow measure of Chinese ownership share that further imposes the all-cashfinancing criterion. The instrument still robustly predicts this narrower outcome. While for measurement, the narrower measure is more precise, for an IV regression, the broader measure is preferred. The false positives in the broad measure will be treated as measurement error, which the IV resolves; by contrast, the true Chinese ownership not captured by the narrow measure will be unobserved error correlated with the narrow measure itself, leading to an upward-biased IV estimates of Chinese ownership on local housing market outcomes.

\subsection{Variation in Graphs}

Before discussing the estimation results, I first turn to raw plots using the same IV variation in Figure 4. These figures highlight the difference-in-difference spirit of the instrumental variable. For each zip code in an MSA, it is first categorized by historical Chinese presence as of 2000 , using $1 \%$ of population share as the cutoff. Then, the largest flight-time change for that zip code over the same period is identified and coded as the event year. Various outcomes variables are then averaged by event year and the Chinese-presence binary, weighing each observation by the 2000 zip-code overall population and the size of the travel-time change. The IV variation can be visualized as the gap between the two lines (difference between the highand low-Chinese-share zip codes), after the event relative to before.

The outcome variable in Figure 4a is the Chinese-owned property share. This plot could be thought of as the first stage. Relative to the event year, we see that Chinese ownership share rises, slightly in the low-Chinese-presence zip codes, but rapidly and gradually in the high-Chinese-presence zip codes, in the years following the event (Figure 4b).

The next figures plot local housing-market outcomes: owner-occupation rate, house price index, con- 
struction rate and two rent indices, one by Zillow at the zip-code level but starting in 2010 and the other by HUD at the county level. The outcomes are broadly consistent with the model presented in this paper. Occupation rate drops immediately for the high-Chinese-presence areas, as many of the Chinese buyers bought to convert them into rental properties.

While for identification I rely on between-zip-code variation, the local-housing-market impact is likely to be broader than zip codes. This is most pronounced for house-price indices in Figure 4c, since buyers arguably have higher elasticity of substitution across zip codes than residents. Because the IV variation only exploits the difference, it is likely that the IV estimates will be biased toward zero, especially for the house-price estimate. Nonetheless, the gap between high- and low-Chinese-present zip codes' house prices still rises. Construction rate gap also rises (Figure 4d).

The main outcome of interest is plotted in Figures 4e and 4f, using Zillow and HUD rent indices, respectively. Both rent data are flawed, with the zip-code-level Zillow index beginning only in 2010 and the longer HUD index varying only at the county-level. Nonetheless, they both show that the gap between zip codes with and without Chinese presence widens, with rent falling where Chinese buyers enter. The rentdrop is immediate, consistent with the model in this paper where quicker conversion of ownership properties to rental properties enables rent to adjust faster than in a classical q-theory model where rent falls only as overall housing supply rises.

These raw variations are consistent with the simple model, and the qualitative patterns will be confirmed in proper estimation in the next subsection.

\subsection{Estimation Results}

Results from IV regressions for local housing market impact are in Table 3 . For US zip code $z$ in Core-Based Statistical Area (CBSA) $m$ in year $t$, the IV specification is

$$
\begin{aligned}
\text { Chinese share }_{z m t} & =\gamma_{0}[\text { Hours }]_{z m t}+\gamma_{1}[\text { Hours }]_{z m t} \times[\text { Has Chinese presence }]_{z}+\delta_{z}+\delta_{m t}+\eta_{z m t} \\
Y_{z m t} & =\beta \text { Chinese share }{ }_{z m t}+\tilde{\gamma}[\text { Hours }]_{z m t}+\alpha_{z}+\alpha_{m t}+\varepsilon_{z m t}
\end{aligned}
$$

All regressions are weighted by zip-code population in 2000 .

The estimation results confirm the graphical analysis in the previous sub-section. Higher Chinese buyer demand raises price, spurs construction, lowers owner-occupancy rate and lowers rent. The two rent estimates differ, as both data have limitations. Zillow rent index starts only in 2010 even though it is at the zip code level. The small sample size reflects that. More problematically, the shorter sample span implies there 
are fewer changes in flight time, i.e. variation in the instrument, hurting statistical power. On the other hand, HUD data span the whole sample, but they are county-level data. This biases estimates toward zero, hence leading to much smaller estimates than for the Zillow rent index.

With the HUD rent data, the longer sample and hence more flight time changes allow for heterogeneity analysis by the elasticity of the housing supply. Splitting areas by the median Saiz (2010) elasticity of 1.5 in the sample, the last column shows that rents fell in more elastic areas. The heterogeneity in estimates is consistent with the model in this paper. The estimate for inelastic areas is positive, also consistent with the model.

It is worth noting that the IV estimates are much larger than the corresponding OLS correlations. The two likely reasons are that the Chinese share variable is measured with much error and that Chinese buyers' demand - as endogenous decision - is correlated with local conditions. It is also possible that the instrument is not exogenous, which I address below.

One concern is that easier travel from China affects local housing markets through a different channel. For example, tourism may increase due to easier travel, and that can increase real estate values by increasing demand for hotels and other travel-related businesses. I check for this possibility by running placebo regressions of the existence and number of hotels and bed and breakfasts using zip code-level establishment counts from County Business Patterns. I regress present and counts of hotels and bed \& breakfasts in a zip code against the travel time from China, in Online Appendix Table A.3. The coefficients are all statistically indistinguishable from zero.

Lastly, travel time from China should affect mostly Chinese buyers and less so Chinese Americans. The latter effect is not zero, because Chinese buyers can arrive and invite their relatives already in the US. Increase in Chinese landlords can also incentivize more Chinese Americans to enter those areas. Online Appendix Figure A.10b shows that Chinese buyers respond much more strongly to travel time from China than do Chinese Americans. The latter slope is not zero, but still much smaller than the slope for Chinese buyers.

\section{Discussion}

\subsection{Applications and Policy}

This paper studies how buyer entry in the housing market causally impacts the rent level in the local housing market. The empirical estimates derive from a concentrated episode of Chinese buying activity in the US housing market in the recent decade. The model and estimates, however, apply more broadly to other 
applications where high-wealth buyers and investors enter a new market. I discuss three specific examples, whose importance has been rising in society and in the literature.

First and most immediate, international buyers have been prolific in other countries of origin and destination as well. Chinese buyers have been buying properties in various countries, ranging from Korea to Australia (Searcey and Bradsher (2015)), and Russian buyers have been active in the European housing market (Moss (2014)). While details of the buyers as well as of local housing market infrastructure differ, the general q-theory framework developed in this paper applies to these situations as well.

Second, the rental housing market in the US has seen the rise of institutional ownership, even among single-family homes, which have traditionally been the domain of mom-and-pop landlords (Mills et al. (2019)). This change has been eyed with concerns of monopolistic pricing in the rental housing market. Yet, institutional owners do have the advantage that they can pool the idiosyncratic risk inherent in owning a home as an asset. Diversification, especially when the institutional owners span multiple geographical markets, can lower the effective discount factor, and translate to lower rent for renters. The estimates and the framework developed in this paper can discipline the cost-benefit analysis of the changing rental landscape.

Third, in discussions surrounding neighborhood gentrification, one of the concerns is that incoming residents with higher incomes than the existing residents will lead to higher rents for existing renters. Yet, because housing is an investment asset that exhibits home bias, the incoming high-income residents also bring in more asset demand, possibly above and beyond their primary residence. This benefit has not been considered in the discussions. In addition, the consideration points to benefits of policies that make it easier to invest in homes as a way to make gentrification more welfare-improving.

More broadly, the gentrification literature often proxies for rent using house price indices, implicitly assuming the price-to-rent ratio is unaffected by the composition of owners. This is understandable given the paucity of reliable rent indices. Nonetheless, this paper shows that high-income buyers' asset demand can lead to a divergence in rent and asset price.

While the paper focuses on housing, the mechanisms outlined apply to real assets and capital more broadly.

The potentially welfare-enhancing impact of capital influx and the forces analyzed in this paper lead to a few policy implications. First, particularly in response to Chinese buyers, some cities have adopted policies to curb such investment activity and their negative consequences. One policy response may be to tax vacancies, which can let in more landlords for rental properties, which can exert a downward pressure on rental prices. Second, some countries impose additional taxes on investment homes to deter speculators. It may be possible to capture the benefits of a larger buyer base by instead taxing short-term investment 
homes only. Third, among assets investment homes pay additional taxes on the asset value in the form of property tax 15 A broader tax base for wealth may lead to more investment into second homes, which can lower rent and contribute positively to the housing affordability crisis. Fourth, the effect of capital influx on aggregate welfare depends on the housing supply elasticity, which modulates the supply-expansion force. Since supply restrictions also impact the effective supply elasticity (Gyourko and Molloy (2015)), relaxing such restrictions can allow foreign and institutional buyers to have more positive welfare impact.

\subsection{Literature Review}

This paper relates to several strands in the literature. Several papers study the impact of foreign investors on house prices: Badarinza and Ramadorai (2018); Sá (2016); Hamnett and Reades (2019) (for UK); Pavlov and Somerville (2017) (for Canada); Cvijanovic and Spaenjers (2018) (for Paris, France); Davids and Georg (2020) (for Cape Town, South Africa); and Been et al. (2019) (for theory). Most related to my paper are several contemporary papers that look at the price impact of Chinese buyers in US housing markets (Gorback and Keys (2020); Li et al. (2020)). I focus on a different question - the spillover effect onto renters - and use a different identification strategy to get the causal impact of Chinese buyers - interacting cost of travel with local Chinese presence.

More broadly, this paper relates to research examining second-home demand and their impact (Chinco and Mayer (2016); Hilber and Schöni (2020); Cvijanovic et al. (2015); Haughwout et al. (2011); Suher (2016); Favilukis and Van Nieuwerburgh (2017); and Bayer et al. (2013)). Papers in these two categories focus on the house-price impact and the general equilibrium impact on local economy, and few papers study the welfare impact. One exception is the structural explorations in Favilukis and Van Nieuwerburgh (2017), which explicitly models the rent-own decision. I complement this literature by focusing on the spillover onto renters as well as the distribution of welfare impact.

I also add to several recent empirical papers that argue for a large supply effect in housing markets: Asquith et al. (2019); Li (2019); Mast (2019); and Pennington (2020).

This paper is complementary to the large and growing economic literature on gentrification ${ }^{16}$ This paper also relates to the recent literature examining the owners of the rental housing stock. In particular, larger institutional investors have come to replace individual owners ("mom-and-pop landlords") as the dominant force (Mills et al. (2019): They also document correlations that higher fraction of buy-to-rent investors is associated with higher house price level but not rent).

\footnotetext{
${ }^{15}$ Average property tax rate is $1.15 \%$ applied to the asset value (Harris et al. (2013)).

${ }^{16}$ The sociological literature on gentrification is even more vast. For a recent review, see Brown-Saracino (2017)
} 
Lastly, direct investment in real estate may be an alternative, under-explored channel of the savings glut hypothesis (Bernanke et al. (2005)). The savings glut hypothesis points to the role of increased savings by Chinese investors in lowering the US interest rate. Discussions around the hypothesis focus on the drastic increase in US Treasury holdings by Chinese and other foreign investors over that period. Much less attention has been paid to the role of foreign investors' direct investment into US real estate.

\subsection{Conclusion}

This paper asks, when there is an influx of capital into an asset market, what are the distributional consequences via asset and rental prices, and how do those consequences depend on asset supply elasticity? I examined this broader theoretical question in the context of Chinese buyers' $\$ 150$ billion investment into US residential real estate in 2010-2019.

In order to overcome the lack of official register on foreign real estate ownership, I identify Chinese buyers in public deed records by using the top 100 common Chinese surnames. I impose further restrictions and run several placebo tests to argue that I am indeed picking up Chinese foreign investors. The resulting data set shows that indeed there was a large increase in assets held by those with Chinese surnames, and that the impact was heterogeneous across the US.

To get at the causal impact of Chinese asset demand on local housing markets, I proposed an instrument that interacts two forces that affect where Chinese buyers were more likely to go. The first is travel time changes due to direct flight route openings from China, as a way to shift Chinese buyers' cost of traveling to the US. The second force is existing Chinese American presence to reduce cultural and informational barriers.

The resulting IV estimates show that Chinese investment demand, proxied for using actual Chinese purchases, had a causal impact in increasing house prices. While the effect on rent is theoretically ambiguous, I find that on average Chinese asset demand lowered rent, by spurring investment as would in the q-theory framework. This effect is concentrated in areas with high supply elasticity, where investment can easily respond to asset demand, increasing housing stock and lowering rent.

The model and empirical estimates in this paper extend to related phenomena of foreign buyers more broadly, increasing presence of well-diversified institutional buyers in rental housing markets, and episodes of gentrification where high-income residents and potential buyers enter a new neighborhood. While the q-theory force likely applies in these other settings, more research is needed to quantify its magnitude as well as competing forces unique to each setting. More broadly, who owns an asset can have real welfare consequences, which may be especially large in housing rental markets given housing's importance. 


\section{References}

Aguiar, M. and Hurst, E. (2013). Deconstructing life cycle expenditure. Journal of Political Economy, 121(3):437-492.

Asquith, B., Mast, E., and Reed, D. (2019). Supply shock versus demand shock: The local effects of new housing in low-income areas. Available at SSRN 3507532.

Badarinza, C. and Ramadorai, T. (2018). Home away from home? foreign demand and london house prices. Journal of Financial Economics, 130(3):532-555.

Battistin, E., Blundell, R., and Lewbel, A. (2009). Why is consumption more log normal than income? gibrat's law revisited. Journal of Political Economy, 117(6):1140-1154.

Bayer, P., Geissler, C., and Roberts, J. W. (2013). Speculators and middlemen: The role of intermediaries in the housing market.

Been, V., Ellen, I. G., and O'Regan, K. (2019). Supply skepticism: Housing supply and affordability. Housing Policy Debate, 29(1):25-40.

Berger, D., Guerrieri, V., Lorenzoni, G., and Vavra, J. (2017). House prices and consumer spending. The Review of Economic Studies, 85(3):1502-1542.

Bernanke, B. S. et al. (2005). The global saving glut and the us current account deficit. Technical report.

Brown-Saracino, J. (2017). Explicating divided approaches to gentrification and growing income inequality. Annual Review of Sociology, 43:515-539.

Campante, F. and Yanagizawa-Drott, D. (2018). Long-range growth: economic development in the global network of air links. The Quarterly Journal of Economics, 133(3):1395-1458.

Charles, K. K., Hurst, E., and Roussanov, N. (2009). Conspicuous consumption and race. The Quarterly Journal of Economics, 124(2):425-467.

Chinco, A. and Mayer, C. (2016). Misinformed speculators and mispricing in the housing market. The Review of Financial Studies, 29(2):486-522.

Cvijanovic, D. and Spaenjers, C. (2018). 'we'll always have paris': Out-of-country buyers in the housing market. Kenan Institute of Private Enterprise Research Paper, (18-25).

Cvijanovic, D., Spaenjers, C., et al. (2015). Real estate as a luxury good: Non-resident demand and property prices in paris. HEC Paris Research Paper No. FiN-2015-1073.

Davids, A. and Georg, C.-P. (2020). The cape of good homes: exchange rate depreciations, foreign demand and house prices. Foreign Demand and House Prices (May 30, 2020).

Davis, M. A. and Ortalo-Magné, F. (2011). Household expenditures, wages, rents. Review of Economic Dynamics, 14(2):248-261.

Favilukis, J. and Van Nieuwerburgh, S. (2017). Out-of-town home buyers and city welfare. The Journal of Finance.

Fortin, N. M., Hill, A. J., and Huang, J. (2014). Superstition in the housing market. Economic Inquiry, 52(3):974-993.

Friedman, M. (1957). A theory of the consumption function. Princeton University Press.

Gorback, C. S. and Keys, B. J. (2020). Global capital and local assets: House prices, quantities, and elasticities. Technical report, National Bureau of Economic Research.

Gordon, J. (2015). Soaring vancouver home prices spur anger toward foreign buyers. Reuters.

Greenwald, D., Guren, A., et al. (2019). Do credit conditions move house prices? Unpublished manuscript, MIT.

Gyourko, J. and Molloy, R. (2015). Regulation and housing supply. In Handbook of regional and urban economics, volume 5, pages 1289-1337. Elsevier.

Hamnett, C. and Reades, J. (2019). Mind the gap: implications of overseas investment for regional house price divergence in britain. Housing Studies, 34(3):388-406.

Harris, B. H., Moore, B. D., and Center, U.-B. T. P. (2013). Residential property taxes in the united states. Urban-Brookings Tax Policy Center Working Paper.

Haughwout, A., Lee, D., Tracy, J. S., and Van der Klaauw, W. (2011). Real estate investors, the leverage cycle, and the housing market crisis. FRB of New York Staff Report, (514).

He, Z., Hu, M. R., Wang, Z., and Yao, V. (2020). Political uncertainty and asset valuation: Housing prices in hong kong. Technical report, National Bureau of Economic Research.

Henry de Frahan, L. and Sakong, J. (2020). Intergenerational elasticity of consumption and income. 
Hilber, C. A. and Schöni, O. (2020). On the economic impacts of constraining second home investments. Journal of Urban Economics, page 103266.

Kaplan, G., Mitman, K., and Violante, G. L. (2017). The housing boom and bust: Model meets evidence. Technical report, National Bureau of Economic Research.

Kaplan, G. and Violante, G. L. (2014). A model of the consumption response to fiscal stimulus payments. Econometrica, 82(4):1199-1239.

$\mathrm{Li}, \mathrm{X}$. (2019). Do new housing units in your backyard raise your rents. Technical report, Working paper.

Li, Z., Shen, L. S., and Zhang, C. (2020). Capital flows, asset prices, and the real economy: A" china shock" in the us real estate market.

Mari, F. (2020). A $\$ 60$ billion housing grab by wall street. The New York Times. Accessed: 2021-06-10.

Mast, E. (2019). The effect of new market-rate housing construction on the low-income housing market. Upjohn Institute WP, pages 19-307.

Meyer, B. D. and Sullivan, J. X. (2017). Consumption and income inequality in the us since the 1960s. Technical report, National Bureau of Economic Research.

Mian, A. and Sufi, A. (2011). House prices, home equity-based borrowing, and the us household leverage crisis. The American Economic Review, 101(5):2132-2156.

Mian, A. and Sufi, A. (2014). What explains the 2007-2009 drop in employment? Econometrica, 82(6):2197-2223.

Mills, J., Molloy, R., and Zarutskie, R. (2019). Large-scale buy-to-rent investors in the single-family housing market: The emergence of a new asset class. Real Estate Economics, 47(2):399-430.

Modigliani, F. and Brumberg, R. (1954). Utility analysis and the consumption function: An interpretation of cross-section data. Franco Modigliani, 1(1):388-436.

Moss, S. (2014). Why are rich russians so obsessed with buying up london property?

Nathanson, C. G. and Zwick, E. (2017). Arrested development: Theory and evidence of supply-side speculation in the housing market. Technical report, National Bureau of Economic Research.

Pavlov, A. and Somerville, T. (2017). Immigration, capital flows and housing prices. Real Estate Economics.

Pennington, K. (2020). Does building new housing cause displacement?: The supply and demand effects of construction in san francisco.

Piazzesi, M. and Schneider, M. (2016). Housing and macroeconomics. In Handbook of Macroeconomics, volume 2, pages 1547-1640. Elsevier.

Piazzesi, M., Schneider, M., and Tuzel, S. (2007). Housing, consumption and asset pricing. Journal of Financial Economics, 83(3):531-569.

Pristin, T. (2005). Echoes of the 80's: Japanese return to u.s. market.

Rosen, K., Margon, A., Sakamoto, R., and Taylor, J. (2017). Breaking ground: Chinese investment in us real estate. Asia Society.

Sá, F. (2016). The effect of foreign investors on local housing markets: Evidence from the uk.

Saiz, A. (2010). The geographic determinants of housing supply. The Quarterly Journal of Economics, 125(3):1253-1296.

Searcey, D. and Bradsher, K. (2015). Chinese cash floods u.s. real estate market.

Straub, L. (2018). Consumption, savings, and the distribution of permanent income. Unpublished manuscript, Harvard University.

Suher, M. (2016). Is anybody home? the impact and taxation of non-resident buyers. Technical report, Working Paper Furman Center New York University.

US Census Bureau, D. o. C. (1996). Who owns the nation's rental properties? Technical report.

Word, D. L., Coleman, C. D., Nunziata, R., and Kominski, R. (2008). Demographic aspects of surnames from census 2000. Unpublished manuscript, Retrieved from http://citeseerx. ist. psu. edu/viewdoc/download.

Yun, L. and Cororaton, G. (2019). Profile of international activity in u.s. residential real estate 2019. Technical report, National Association of Realtors Research Division.

Yun, L., Hale, D., and Cororaton, G. (2017). 2017 profile of international activity in u.s. residential real estate. Technical report, National Association of Realtors Research Division. 


\section{Figure 1: Model Steady State}

These figures illustrate steady states of the model, without foreign buyers (dashed lines) and with (solid lines). Figure 1a plots housing-quantity demanded $H$ against income level $Y$ from the individual optimization problem. The break in the line indicates renter demand to the left and owner demand to the right. The next three figures illustrate the model equilibrium. The tenure cutoff is determined as in figure 1c, with relative price (price-to-rent ratio) on the Y-axis and the fraction renting (with cutoff given as $\tilde{Y}$ ) on the X-axis: black lines indicate the marginal household's indifference condition, and the gray lines indicate relative-pricing based on tenure shares. Figure $1 \mathrm{~b}$ illustrates the housing asset/investment market, with the housing supply curve in gray and the pricing equation from the net-present-value formula in black. Figure 1d illustrates the housing use market, with the housing stock in gray and aggregated use demand (from renters, domestic owner-occupants and foreign residents) in black.

(a) Housing quantity vs. income

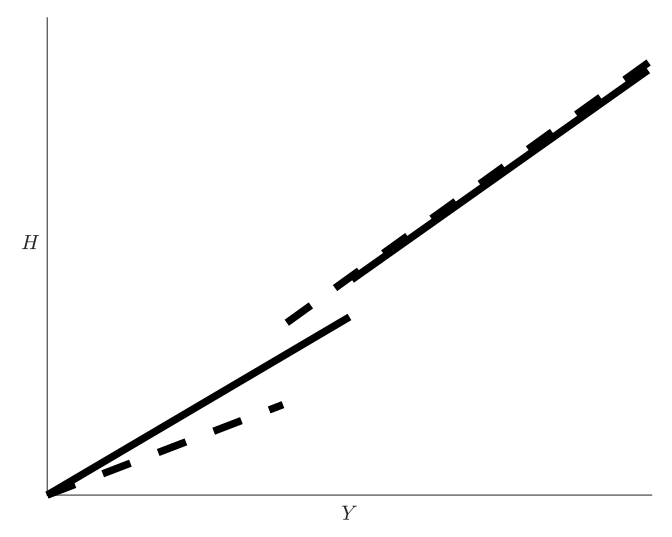

(c) Tenure vs. income

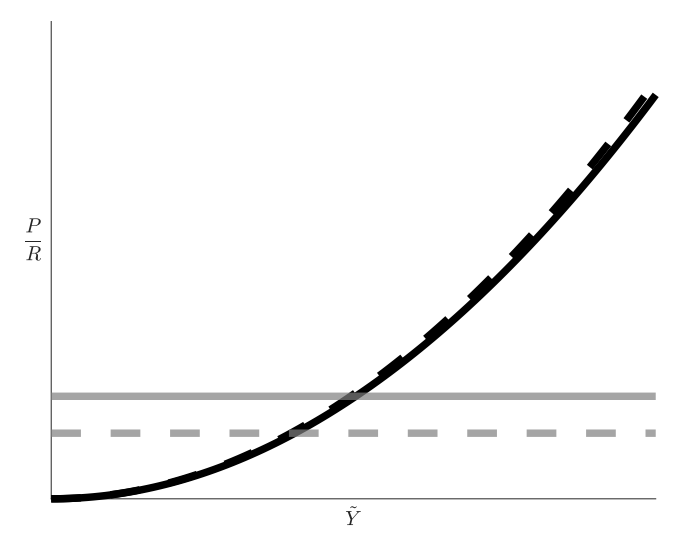

(b) Asset market

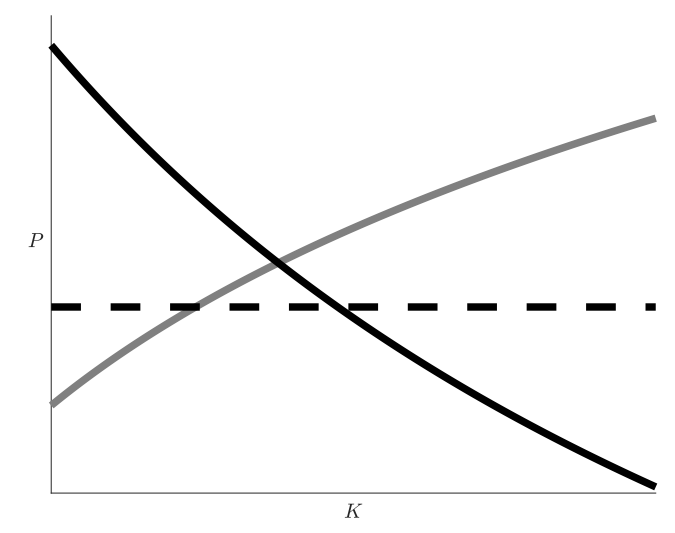

(d) User market

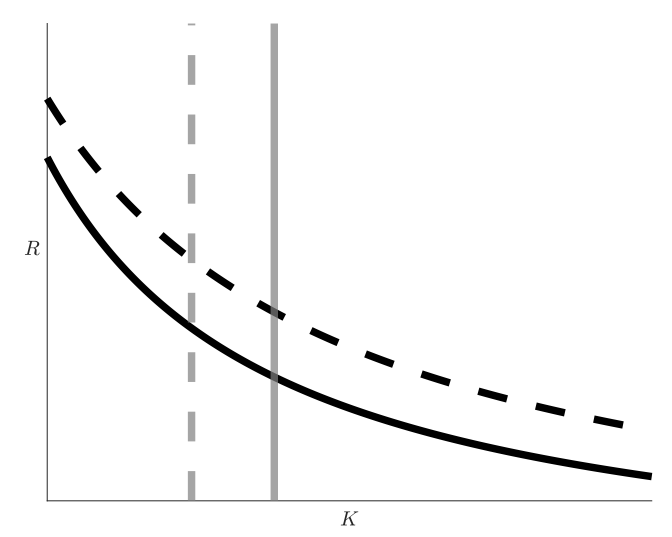




\section{Figure 2: Model Transition Path with Foreign Buyer Entry}

These figures illustrate the transition path of the model housing market following an unexpected entry of foreign buyers at $t=1$. The first four figures plot the following model quantities against time: housing stock (Figure 2a), house price per unit of housing (Figure 2b), fraction of domestic households that rent (Figure 2c), and housing user cost for renters in blue downward-pointing triangles, owners in red upward-pointing triangles and weighted average in black circles (Figure 2d). Figure 2e plots change in utility (both flow and the net present value) in response to the foreign-buyer entry by households' incomes: The thin lines plot flow utility change initially in response to the news (red dotted line), upon the entry (dashed line) and in the new steady state (solid line); the black circles plot the change in the NPV of utility, aggregating flow utility changes with the domestic discount rate $r$. Figure 2f plots the mean utility among domestic households in black circles and the median utility in gray crosses.

(a) Housing stock

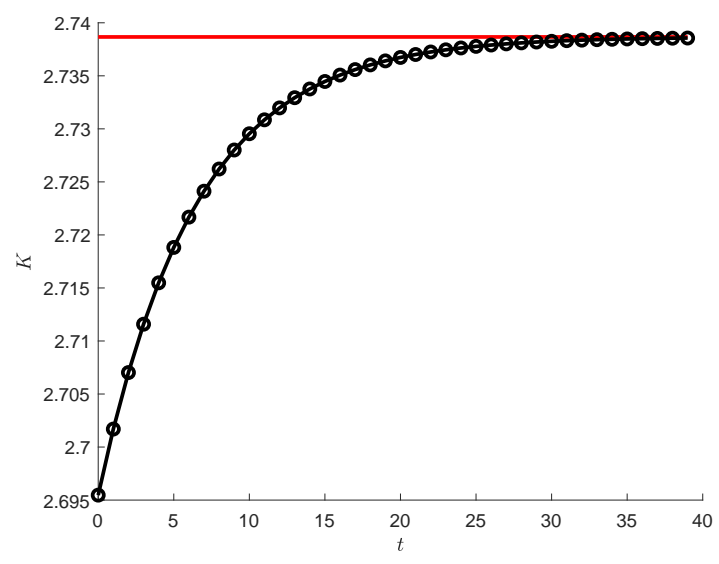

(c) Renter share

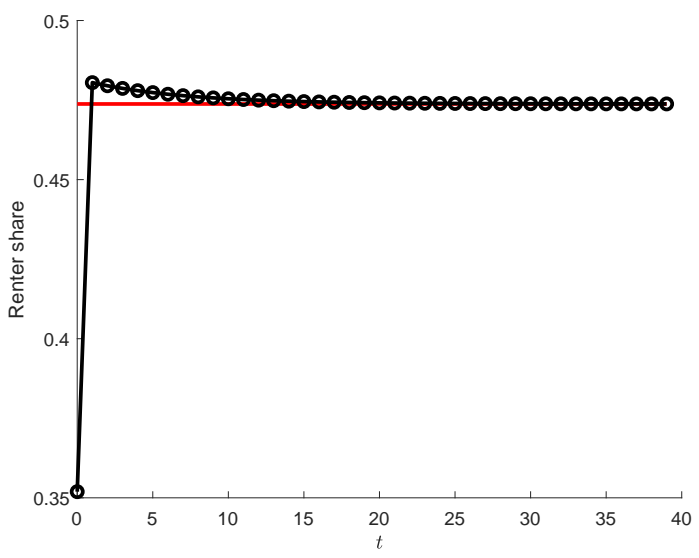

(b) House price

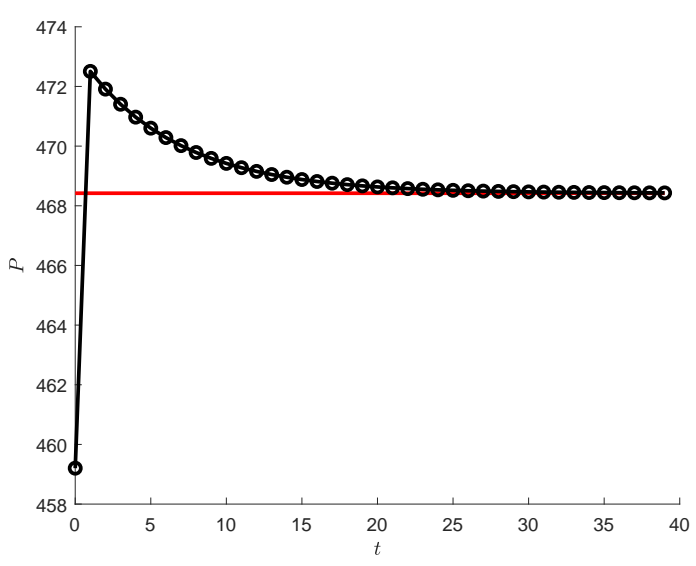

(d) Rent and user cost

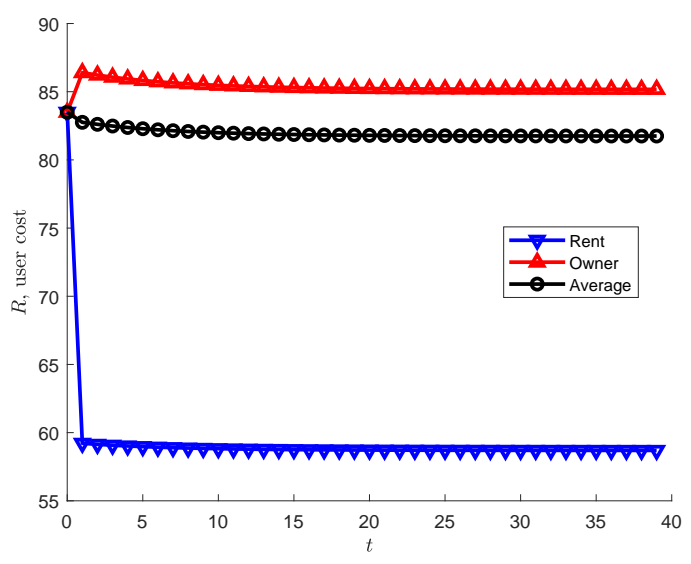


Figure 2: Model Transition Path with Foreign Buyer Entry (continued)

(e) Flow and NPV utility vs. income

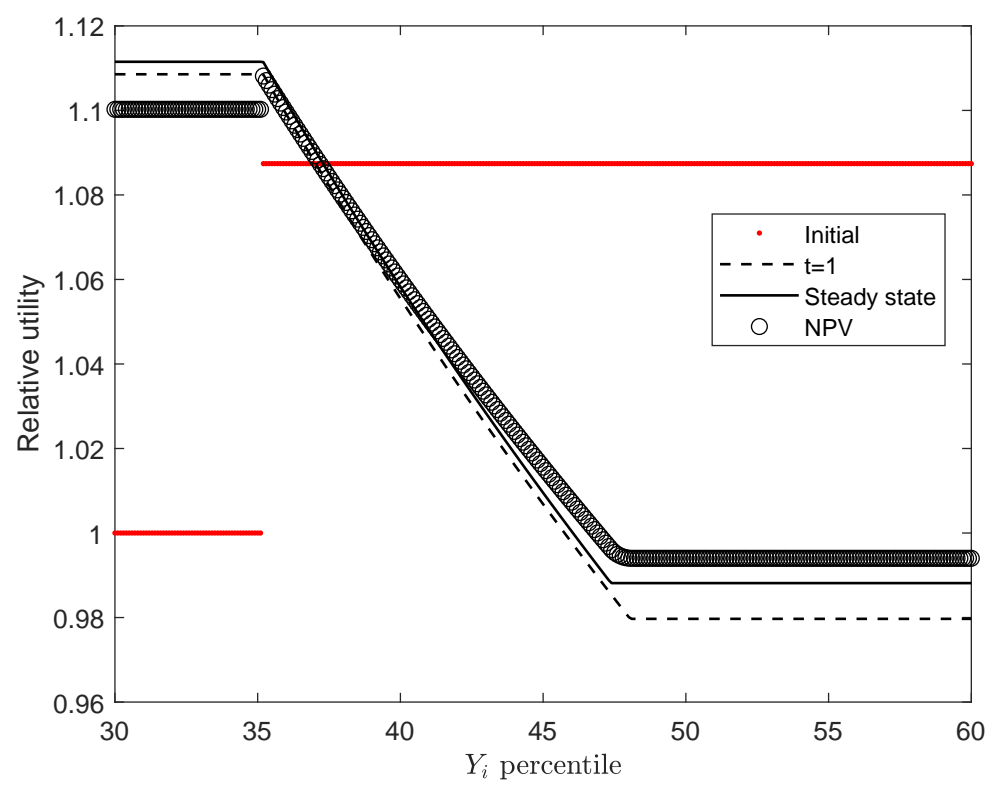

(f) Aggregate utility

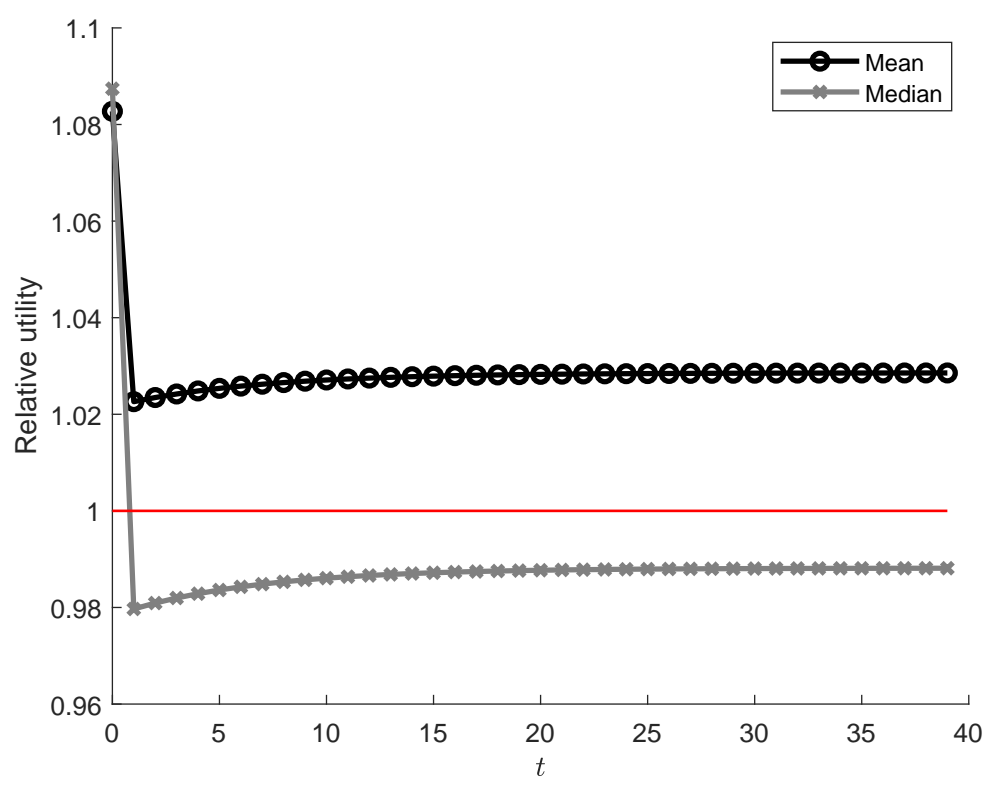




\section{Figure 3: Measured Chinese shares}

These figures plot the measured real estate properties bought or owned by Chinese buyers, identified using the top 100 common Chinese surnames and non-English first names ("broad measure") and all-cash financing in addition ("narrow measure"). Figure 3 a plots monthly gross purchases, with number of properties in blue and total value in red. As opposed to this flow measure, figures $3 \mathrm{~b}$ and $3 \mathrm{c}$ plot stock measure, namely the share of total properties held by Chinese owners, using the narrow and broad measures respectively. Solid lines are shares measured by property counts, dash lines by number of bedrooms, and dotted lines by total square footage.

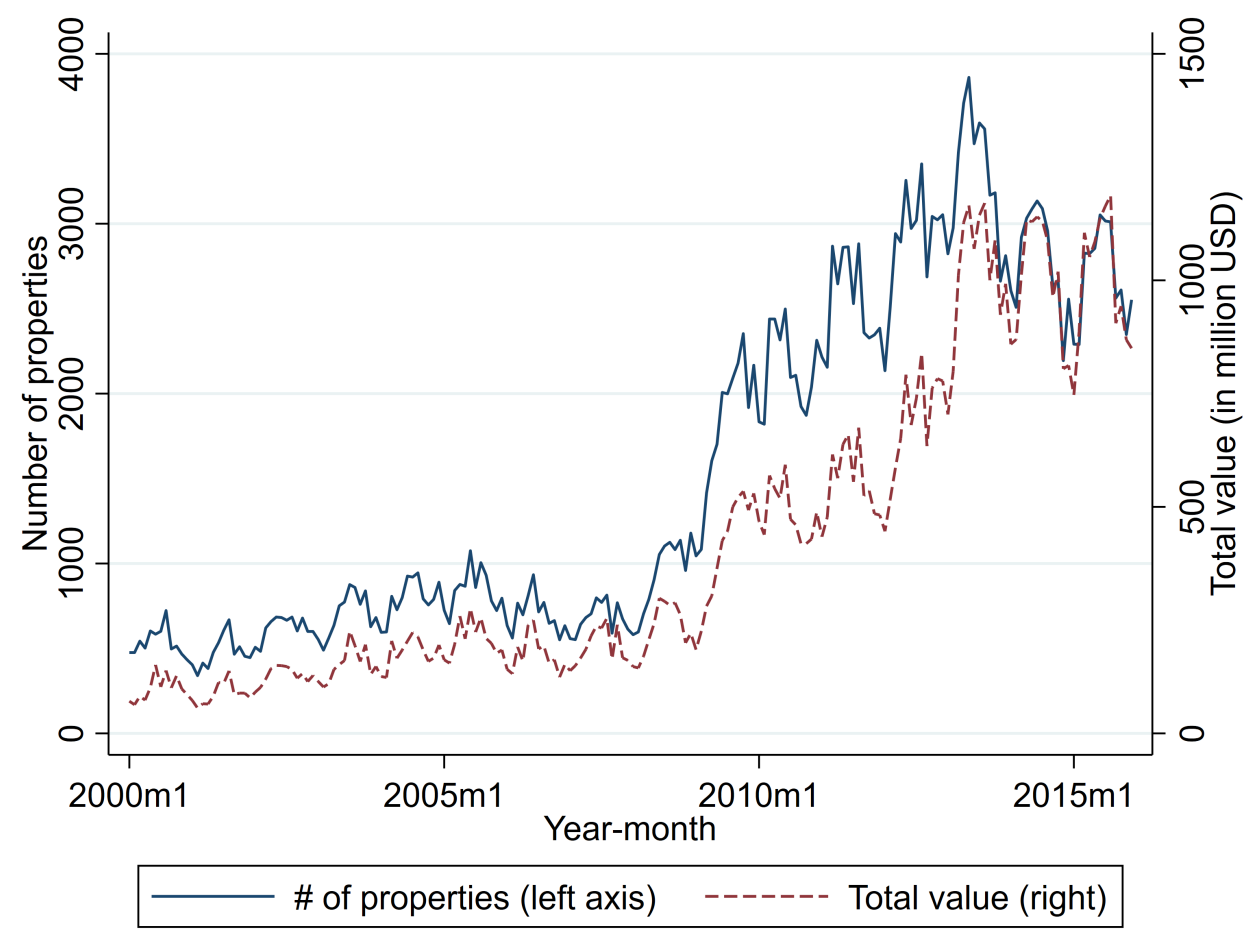

(a) Monthly gross purchases: Narrow measure

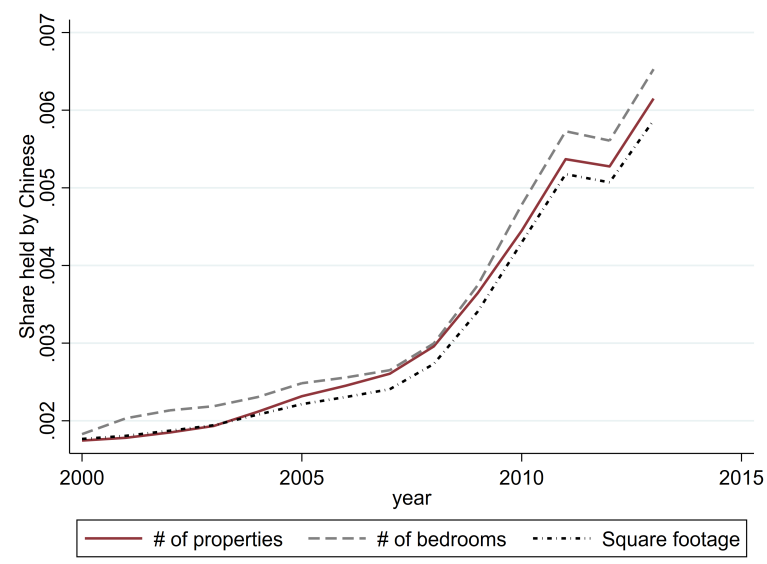

(b) Stock: Narrow measure

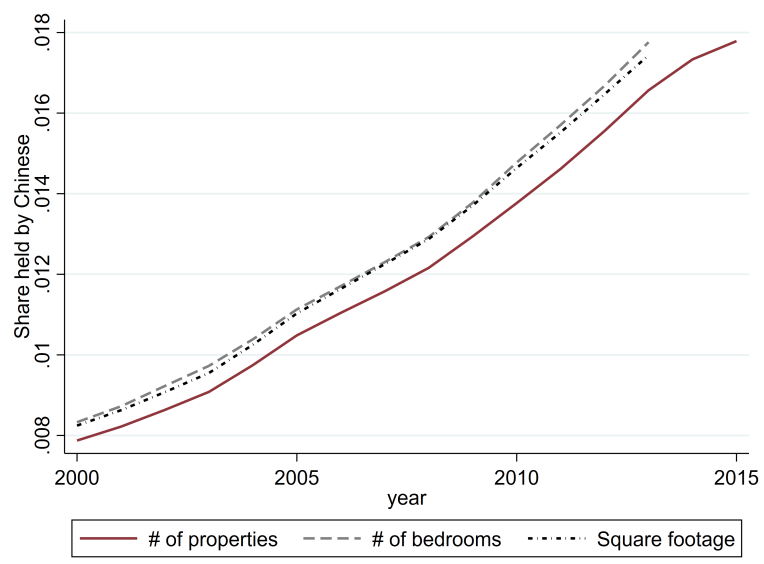

(c) Stock: Broad measure 


\section{Figure 4: First stage and reduced form}

These figures plot key housing market outcomes for zip codes with major pre-existing Chinese presence in 2000 (maroon solid lines) and other zip codes in metropolitan areas (grey dashed lines) along with their 95\% confidence intervals, in years relative to an event year in which its main flight-time reduction took place (i.e. in event time). In constructing the averages, year $\times$ zip code observations are weighed by both the 2000 population of the zip code and the magnitude of the reduction in travel time from China. See main text for detailed variable descriptions and data sources.

(a) Chinese-owned property share (first stage)

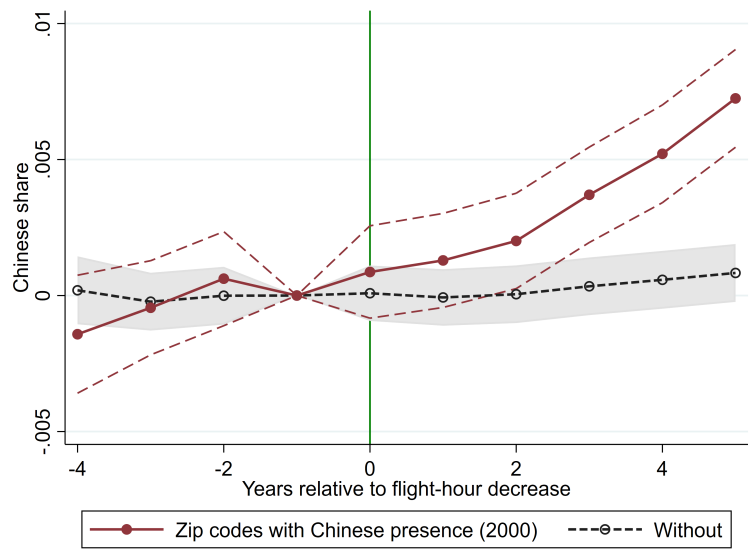

(c) House price

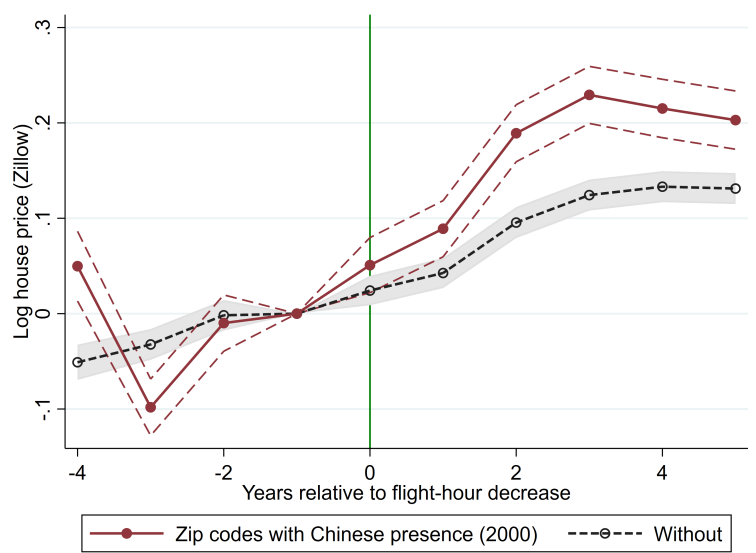

(e) Rent (Zillow)

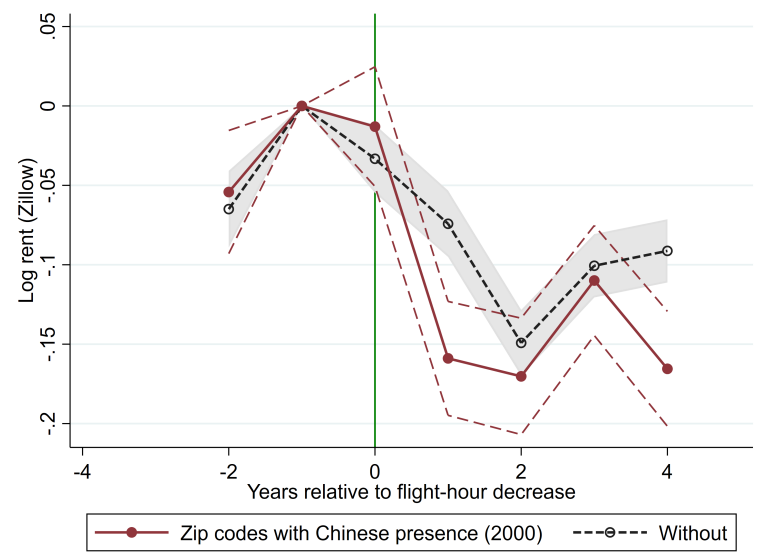

(b) Owner-occupation rate

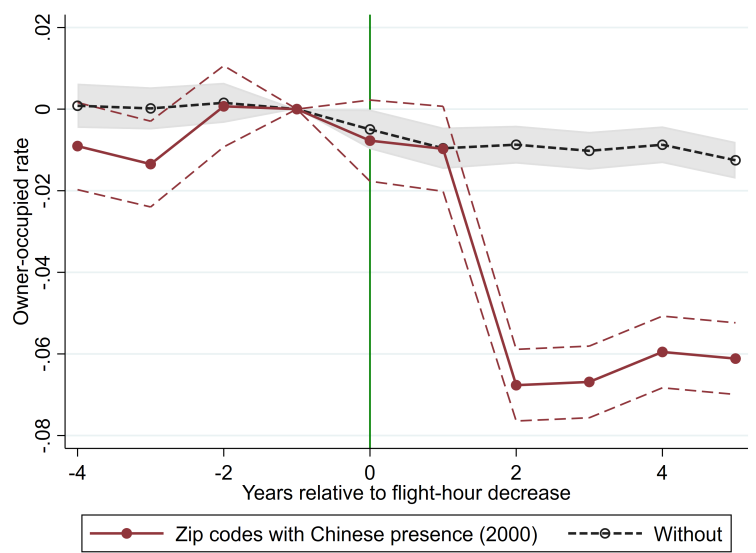

(d) Construction rate

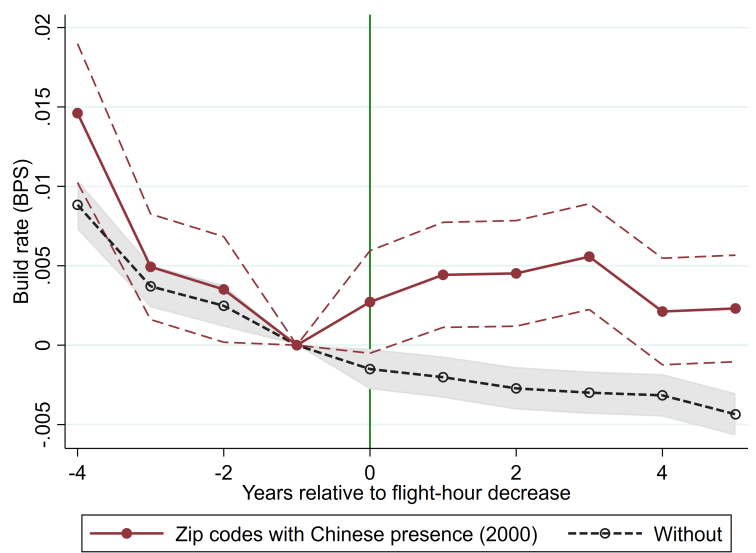

(f) Rent (HUD)

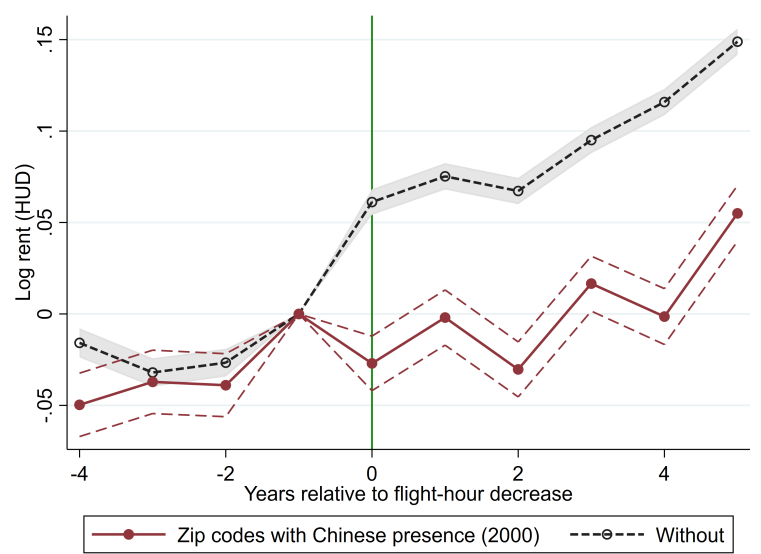




\section{Table 1: Summary statistics: Chinese-owned properties}

This table reports summary statistics of real-estate properties from the CoreLogic data, averaged over years 2009-2014. The first column is for properties with identified Chinese owners (top 100 Chinese surnames and non-English first names). The second column is for all residential properties in the CoreLogic sample for comparison (see Online Appendix Figure A.3 for counties in the sample). The first panel reports propertylevel characteristics. The bottom panel reports average location characteristics, using the zip codes in which the properties are located in. Unless otherwise noted, zip-code level data are for 2010. House price and rent averages are from Zillow's zip-code indices. Housing supply elasticity is from Saiz (2010). For hours from China, see Section 4.2. Other zip-code data are from the 2010 Census.

\begin{tabular}{|c|c|c|c|c|c|}
\hline & Chinese & All & & Chinese & All \\
\hline \multicolumn{6}{|c|}{ Property characteristics } \\
\hline Average: & & & Fraction owned (\%): & & \\
\hline Value & 300,890 & 187,197 & By count & 0.81 & \\
\hline Bedrooms & 2.34 & 1.72 & By value & 1.30 & \\
\hline Square footage & 2,064 & 2,370 & By square footage & 0.70 & \\
\hline & & & By bedrooms & 1.10 & \\
\hline Housing type: & & & Deed tenure: & & \\
\hline Single Family & 0.68 & 0.67 & Owner-occupied & 0.72 & 0.73 \\
\hline Condo & 0.15 & 0.07 & Absentee & 0.28 & 0.27 \\
\hline Apartment & 0.02 & 0.02 & Corporate own: & 0.00 & 0.10 \\
\hline \multicolumn{6}{|c|}{ Location characteristics (zip code) } \\
\hline Zillow house price & 363,223 & 249,926 & Hours from China & 17.8 & 19.0 \\
\hline Zillow rent & 1,600 & 1,259 & Housing supply & 1.17 & 1.50 \\
\hline Median income & 73,468 & 63,904 & elasticity & & \\
\hline Homeowner & 0.62 & 0.67 & Urban & 0.98 & 0.90 \\
\hline Chinese (2000) & 0.05 & 0.01 & Census regions: & & \\
\hline Asian & 0.18 & 0.05 & Northeast & 0.19 & 0.18 \\
\hline Black & 0.09 & 0.11 & Midwest & 0.08 & 0.16 \\
\hline Hispanic & 0.17 & 0.14 & South & 0.21 & 0.34 \\
\hline White & 0.65 & 0.77 & West & 0.52 & 0.32 \\
\hline
\end{tabular}




\section{Table 2: First stage}

This table reports the first-stage regressions of Chinese-owned property shares on minimum travel time from China, interacted with pre-existing Chinese presence (defined as having at least $1 \%$ Chinese population share in 2000). For US zip code $z$ in Core-Based Statistical Area (CBSA) $m$ in year $t$, the main specification in column (3) is

$$
\text { Chinese share } z_{z m t}=\gamma_{0}[\text { Hours }]_{z m t}+\gamma_{1}[\text { Hours }]_{z m t} \times[\text { Has Chinese presence }]_{z}+\delta_{z}+\delta_{m t}+\eta_{z m t}
$$

where "Hours" refers to the predicted travel time using the 1997 domestic-flight network with each year's direct flight from China in the main specification. Relative to this main specification, column (2) replaces the year $\times$ CBSA fixed effects with just year fixed effects. Column (1) reports just the cross-sectional relationship between predicted travel time and Chinese property shares. Column (4) removes the Hours itself as a regressor, since much of its variation is absorbed by the year $\times$ CBSA fixed effects. Column (5) uses actual Chinese population share in 2000 instead of indicator for having at least $1 \%$. Column (6) uses the actual travel time instead of the predicted flight time from China. Column (7) uses the narrow measure of Chinese property share (further imposing all-cash financing) as the outcome variable. All regressions are weighted by area population. Robust standard errors are reported in parentheses.

\begin{tabular}{|c|c|c|c|c|c|c|c|}
\hline & \multicolumn{6}{|c|}{ Chinese share (broad) } & \multirow{2}{*}{$\frac{(\text { Narrow })}{(7)}$} \\
\hline & (1) & (2) & (3) & (4) & (5) & (6) & \\
\hline $\begin{array}{l}\text { Hours (1997 layout) } \\
\times \text { Chinese presence }\end{array}$ & & $\begin{array}{l}-0.269 \\
(0.009)\end{array}$ & $\begin{array}{l}-0.237 \\
(0.009)\end{array}$ & $\begin{array}{l}-0.237 \\
(0.009)\end{array}$ & & & $\begin{array}{l}-0.099 \\
(0.007)\end{array}$ \\
\hline Hours (1997 layout) & $\begin{array}{l}-0.398 \\
(0.007)\end{array}$ & $\begin{array}{c}0.102 \\
(0.007)\end{array}$ & $\begin{array}{l}-0.027 \\
(0.009)\end{array}$ & & $\begin{array}{l}-0.016 \\
(0.009)\end{array}$ & & $\begin{array}{l}-0.025 \\
(0.003)\end{array}$ \\
\hline $\begin{array}{l}\text { Hours (1997 layout) } \\
\times \text { share Chinese }\end{array}$ & & & & & $\begin{array}{l}-4.749 \\
(0.596)\end{array}$ & & \\
\hline $\begin{array}{l}\text { Hours (actual) } \\
\times \text { Chinese presence }\end{array}$ & & & & & & $\begin{array}{l}-0.237 \\
(0.009)\end{array}$ & \\
\hline Constant & $\begin{array}{l}9.046 \\
(0.139)\end{array}$ & $\begin{array}{c}0.395 \\
(0.125)\end{array}$ & $\begin{array}{c}2.800 \\
(0.195)\end{array}$ & $\begin{array}{c}2.280 \\
(0.037)\end{array}$ & $\begin{array}{c}2.598 \\
(0.185)\end{array}$ & $\begin{array}{c}2.277 \\
(0.037)\end{array}$ & $\begin{array}{c}1.207 \\
(0.086)\end{array}$ \\
\hline Observations & 175196 & 175196 & 172498 & 172498 & 172498 & 172498 & 151830 \\
\hline Adjusted $R^{2}$ & 0.070 & 0.669 & 0.727 & 0.727 & 0.728 & 0.727 & 0.853 \\
\hline Partial F-stat & & 809 & 661 & 660 & 63 & 658 & 179 \\
\hline Year FE & $\mathrm{O}$ & $\mathrm{O}$ & & & & & \\
\hline Zip code FE & & $\mathrm{O}$ & $\mathrm{O}$ & $\mathrm{O}$ & $\mathrm{O}$ & $\mathrm{O}$ & $\mathrm{O}$ \\
\hline Year $\times$ CBSA FE & & & $\mathrm{O}$ & $\mathrm{O}$ & $\mathrm{O}$ & $\mathrm{O}$ & $\mathrm{O}$ \\
\hline
\end{tabular}




\section{Table 3: Housing Market Impact}

The top panel reports instrumental-variable (IV) regressions of housing market outcomes on Chinese-owned property shares, instrumented using an interaction between predicted travel times from China and preexisting Chinese population shares in 2000, i.e. column (3) in Table 2, For US zip code $z$ in Core-Based Statistical Area (CBSA) $m$ in year $t$, the IV specification is

$$
\begin{aligned}
\text { Chinese share } \text { s }_{z m t} & =\gamma_{0}[\text { Hours }]_{z m t}+\gamma_{1}[\text { Hours }]_{z m t} \times[\text { Has Chinese presence }]_{z}+\delta_{z}+\delta_{m t}+\eta_{z m t} \\
Y_{z m t} & =\beta \text { Chinese share } \text { shmt }_{z m}+\tilde{\gamma}[\text { Hours }]_{z m t}+\alpha_{z}+\alpha_{m t}+\varepsilon_{z m t}
\end{aligned}
$$

Coefficient estimates for travel time $(\tilde{\gamma})$ are omitted in the table below. The outcome variables are log Zillow house price index (zip code), number of residential properties in $\log$ (zip code), building rate as measured by permit count from Building Permits Survey (county), owner occupation rate from the American Community Survey (county), log Zillow rent index (zip code), and log median rent from the Department of Housing and Urban Development (county). The last column separately estimates by CBSAs with high and low housing supply elasticity, relative to median of 1.5 (Saiz (2010)). The bottom panel reports corresponding ordinary least squares (OLS) regressions of the same outcome variables on Chinese-owned property shares, replacing year $\times$ CBSA fixed effects with year fixed effects. All regressions are weighted by area population. Robust

\begin{tabular}{|c|c|c|c|c|c|c|c|}
\hline \multirow[b]{3}{*}{ Chinese share } & \multicolumn{7}{|c|}{ IV estimates } \\
\hline & \multirow{2}{*}{$\begin{array}{c}\text { Price } \\
5.301 \\
(0.354)\end{array}$} & \multirow{2}{*}{$\begin{array}{c}\text { \# prop } \\
9.466 \\
(7.346)\end{array}$} & \multirow{2}{*}{$\begin{array}{c}\text { Build rate } \\
0.430 \\
(0.153)\end{array}$} & \multirow{2}{*}{$\begin{array}{c}\text { Owner occ } \\
-0.375 \\
(0.064)\end{array}$} & \multirow{2}{*}{$\begin{array}{c}\text { Rent }(Z) \\
-1.945 \\
(1.094)\end{array}$} & \multicolumn{2}{|c|}{ Rent (HUD) } \\
\hline & & & & & & $\begin{array}{l}-0.080 \\
(0.045)\end{array}$ & \\
\hline $\begin{array}{l}\text { Chinese share } \\
\text { (inelastic) }\end{array}$ & & & & & & & $\begin{array}{c}0.170 \\
(0.044)\end{array}$ \\
\hline $\begin{array}{l}\text { Chinese share } \\
\text { (elastic) }\end{array}$ & & & & & & & $\begin{array}{l}-0.651 \\
(0.127)\end{array}$ \\
\hline Observations & 157142 & 121542 & 71698 & 106702 & 42575 & 145193 & 101047 \\
\hline Zip code FE & $\mathrm{O}$ & $\mathrm{O}$ & $\mathrm{O}$ & $\mathrm{O}$ & $\mathrm{O}$ & $\mathrm{O}$ & $\mathrm{O}$ \\
\hline \multirow[t]{2}{*}{ Year $\times$ CBSA FE } & $\mathrm{O}$ & $\mathrm{O}$ & $\mathrm{O}$ & $\mathrm{O}$ & $\mathrm{O}$ & $\mathrm{O}$ & $\mathrm{O}$ \\
\hline & \multicolumn{7}{|c|}{ OLS estimates } \\
\hline Chinese share & $\begin{array}{c}0.340 \\
(0.103)\end{array}$ & $\begin{array}{c}1.776 \\
(0.637)\end{array}$ & $\begin{array}{c}0.002 \\
(0.003)\end{array}$ & $\begin{array}{c}0.004 \\
(0.002)\end{array}$ & $\begin{array}{c}0.036 \\
(0.017)\end{array}$ & $\begin{array}{c}0.020 \\
(0.010)\end{array}$ & \\
\hline $\begin{array}{l}\text { Chinese share } \\
\text { (inelastic) }\end{array}$ & & & & & & & $\begin{array}{c}0.370 \\
(0.111)\end{array}$ \\
\hline $\begin{array}{l}\text { Chinese share } \\
\text { (elastic) }\end{array}$ & & & & & & & $\begin{array}{l}-0.012 \\
(0.008)\end{array}$ \\
\hline Observations & 159616 & 123881 & 74290 & 108300 & 43203 & 148059 & 101934 \\
\hline Adjusted $R^{2}$ & 0.961 & 0.266 & 0.761 & 0.986 & 0.971 & 0.955 & 0.949 \\
\hline Zip code FE & $\mathrm{O}$ & $\mathrm{O}$ & $\mathrm{O}$ & $\mathrm{O}$ & $\mathrm{O}$ & $\mathrm{O}$ & $\mathrm{O}$ \\
\hline Year FE & $\mathrm{O}$ & $\mathrm{O}$ & $\mathrm{O}$ & $\mathrm{O}$ & $\mathrm{O}$ & $\mathrm{O}$ & $\mathrm{O}$ \\
\hline
\end{tabular}
standard errors are reported in parentheses. 


\section{A Proofs}

\section{A.1 Tenure Sorting}

The additional coefficient $\theta$ affects the own-rent decision, but conditional on owning, the endogenous choice is analogous to the case of Cobb-Douglas with elasticity $\frac{\theta \alpha}{\theta \alpha+1-\alpha}$ on housing. The optimal choices are,

$$
\begin{aligned}
& H_{\text {own }}=\frac{\theta \alpha}{\theta \alpha+1-\alpha} \frac{Y}{P-P^{\prime} \frac{1-\delta}{1+r}} \\
& H_{\text {rent }}=\alpha \frac{Y}{R}
\end{aligned}
$$

Conjecture that households with income $Y_{i}>\tilde{Y}$ choose owner-occupancy. For the marginal household with income $\tilde{Y}$, the following utility indifference holds:

Importantly, the LHS of the indifference equation (i.e. the relative utility benefit of owning) is increase in $Y$, so that households with higher income will indeed sort into owning. The share spent on housing for owners is greater than for renters, i.e. $\frac{\theta \alpha}{\theta \alpha+1-\alpha}>\alpha$, which needs to be reconciled.

The pricing equation is therefore given by,

Note that the constant $\Upsilon<0$ for our parameter configuration, and so $e^{\frac{\Upsilon}{\theta \alpha}} \in(0,1)$. To see this, first note that $\left.\Upsilon\right|_{\theta=1}=0$ and

$$
\begin{aligned}
\frac{d \Upsilon}{d \theta} & =\alpha \log (\theta \alpha)+\alpha-\alpha \log (\theta \alpha+1-\alpha)-\theta \alpha \frac{\alpha}{\theta \alpha+1-\alpha} \\
& <\alpha\left[\log (\theta \alpha+1-\alpha)+\frac{1}{\theta \alpha+1-\alpha}(-(1-\alpha))\right]+\alpha-\alpha \log (\theta \alpha+1-\alpha)-\theta \alpha \frac{\alpha}{\theta \alpha+1-\alpha} \\
& =0
\end{aligned}
$$

where the inequality follows from the fact that log is a strictly concave function for positive domain (i.e. tangent is always above the function).

\section{A.2 Comparative Static in $F$}

In a comparative static with $F \uparrow$, cannot have both $K \downarrow$ and $\frac{F}{K} \downarrow$. Key is to show that $P$ and $\frac{F}{K}$ responds in the same direction. When $F \uparrow$, it is impossible to have both $K \downarrow$ and $\frac{F}{K} \downarrow$. Hence, either both go up (along with $P$ ), or they move in opposite direction. My conjecture is that they both go up, in which case $I \uparrow$ and $P \uparrow$ from asset supply, $\frac{P}{R} \uparrow$ from landlord valuation, $\tilde{Y} \uparrow$ from marginal-household indifference. $R$ direction would depend.

I try to rule out the other two possibilities (where $K$ and $\frac{F}{K}$ move in opposite direction) by contradiction.

Case 1: If $\frac{F}{K} \downarrow$, then $K \uparrow$ and $P \uparrow$ from supply, $\frac{P}{R} \downarrow$ from arbitrage and hence $R \uparrow \uparrow$. From marginal household, $d \log \tilde{Y}<d \log P<d \log R$.

Case 2: If $\frac{F}{K} \uparrow$ and $K \downarrow$, then $P \downarrow$ from supply, $\frac{P}{R} \uparrow$ from arbitrage and hence $R \downarrow \downarrow$. From marginal household, $d \log \tilde{Y}>d \log P>d \log R$.

The first-order price effect is straight-forward and contrary to the two postulated sign changes. The key is to show that the endogenous, extensive-margin response of $\tilde{Y}$ does not undo the direct effect, but just mitigates it (which it should). 
Leibniz rule with respect to $F$ for the user-market equation:

$$
\begin{aligned}
& \frac{d K}{d F} \underbrace{\left(1-\pi \frac{F}{K}\right)}_{>0}-\pi K \frac{d\left(\frac{F}{K}\right)}{d F} \\
& =-\frac{\alpha}{R} \frac{d \log R}{d F} \int_{\underline{Y}}^{\tilde{Y}} Y_{i} d G\left(Y_{i}\right)-\frac{\theta \alpha}{\theta \alpha+1-\alpha} \frac{1}{P\left(1-\frac{1-\delta}{1+r}\right)} \frac{d \log P}{d F} \int_{\tilde{Y}}^{\bar{Y}} Y_{i} d G\left(Y_{i}\right) \\
& +\frac{d \tilde{Y}}{d F} \tilde{Y} g(\tilde{Y}) \frac{\alpha}{R}-\frac{d \tilde{Y}}{d F} \tilde{Y} g(\tilde{Y}) \frac{\theta \alpha}{\theta \alpha+1-\alpha} \frac{1}{P\left(1-\frac{1-\delta}{1+r}\right)} \\
& =-\frac{\alpha}{R} \frac{d \log R}{d F} \int_{\underline{Y}}^{\tilde{Y}} Y_{i} d G\left(Y_{i}\right)-\frac{\theta \alpha}{\theta \alpha+1-\alpha} \frac{1}{P\left(1-\frac{1-\delta}{1+r}\right)} \frac{d \log P}{d F} \int_{\tilde{Y}}^{\bar{Y}} Y_{i} d G\left(Y_{i}\right) \\
& +\tilde{Y}^{2} g(\tilde{Y})\left[\frac{\alpha}{R}-\frac{\theta \alpha}{\theta \alpha+1-\alpha} \frac{1}{P\left(1-\frac{1-\delta}{1+r}\right)}\right]\left[\frac{\theta}{\theta-1} \frac{d \log P}{d F}-\frac{1}{\theta-1} \frac{d \log R}{d F}\right] \\
& =\frac{d \log P}{d F} \underbrace{\left[-\frac{\frac{\theta \alpha}{\theta \alpha+1-\alpha}}{P\left(1-\frac{1-\delta}{1+r}\right)} \int_{\tilde{Y}}^{\bar{Y}} Y_{i} d G\left(Y_{i}\right)+\frac{\theta}{\theta-1}\left(\frac{\alpha}{R}-\frac{\frac{\theta \alpha}{\theta \alpha+1-\alpha}}{P\left(1-\frac{1-\delta}{1+r}\right)}\right) \tilde{Y}^{2} g(\tilde{Y})\right]}_{\equiv \Phi_{P}} \\
& +\frac{d \log R}{d F} \underbrace{\left[-\frac{\alpha}{R} \int_{\underline{Y}}^{\tilde{Y}} Y_{i} d G\left(Y_{i}\right)-\frac{1}{\theta-1}\left(\frac{\alpha}{R}-\frac{\frac{\theta \alpha}{\theta \alpha+1-\alpha}}{P\left(1-\frac{1-\delta}{1+r}\right)}\right) \tilde{Y}^{2} g(\tilde{Y})\right]}_{\equiv \Phi_{R}}
\end{aligned}
$$

where the second equality uses $\frac{d \log \tilde{Y}}{d F}=\frac{d \tilde{Y}}{d F} \frac{1}{\tilde{Y}}$ and $\frac{d \log \tilde{Y}}{d F}=\frac{\theta}{\theta-1} \frac{d \log P}{d F}-\frac{1}{\theta-1} \frac{d \log R}{d F}$ from the marginalhousehold-indifference equation.

Contradictions of both Case 1 and Case 2 follow if $\Phi_{P} \leq 0$ and $\Phi_{R} \leq 0$.

From the distributional assumption $\left(g^{\prime}(Y) \leq 0\right.$ everywhere) and using integration by parts,

$$
\int_{\tilde{Y}}^{\bar{Y}} Y_{i} d G\left(Y_{i}\right)=\frac{1}{2} \tilde{Y}^{2} g(\tilde{Y})-\frac{1}{2} \int_{\tilde{Y}}^{\bar{Y}} Y_{i}^{2} g^{\prime}\left(Y_{i}\right) d Y_{i} \geq \frac{1}{2} \tilde{Y}^{2} g(\tilde{Y})
$$

This assumption along with $\theta \geq \frac{1-\alpha}{\alpha}$ implies $\Phi_{R} \leq 0 . \frac{r+\delta}{(1+r) \delta} \leq \frac{1}{\alpha}$ further implies $\left(\Phi_{P}+\Phi_{R}\right) \leq 0$.

The second part of the proposition argues that the relative level of $R$ depends on parameter configurations. Numerical examples within the assumptions suffice, using $Y \sim U[0,1]$. For an example where $R$ is higher with a higher $F$, consider $\alpha=0.3, \theta=2.4, \delta=0.1, \kappa=0.5, r=0.03, \varepsilon=0.2, r^{F}=0, \pi=1$, $F_{0}=0$ and $F_{1}=2$. For an example where $R$ is lower with a higher $F$, consider $\alpha=0.3, \theta=3, \delta=0.1$, $\kappa=0.2, r=0.1, \varepsilon=10, r^{F}=0, \pi=0.5, F_{0}=0$ and $F_{1}=0.5$.

\section{A.3 Special Case: Closed-form for $R$}

At the baseline steady state with $F=0$, landlord arbitrage yields $R=P\left(1-\frac{1-\delta}{1+r}\right)$, and $H_{\mathrm{own}}\left(Y_{i}\right)>$ $H_{\text {rent }}\left(Y_{i}\right)$ for all $Y_{i}$. The marginal-household's indifference equation simplifies to, $R=\tilde{Y} e^{\frac{r}{\alpha(\theta-1)}}$. With the assumption of uniform income distribution, the usage market-clearing simplifies to,

$$
R K=\alpha\left(\frac{1}{2} \tilde{Y}^{2}\right)+\frac{\theta \alpha}{\theta \alpha+1-\alpha}\left(\frac{1-\tilde{Y}^{2}}{2}\right)
$$


With an additional simplifying assumption of $\varepsilon=1$, we get a simple closed-form solution for rent,

$$
R=\sqrt{\frac{\frac{\theta \alpha}{2(\theta \alpha+1-\alpha)}}{\frac{\kappa}{\delta \frac{r+\delta}{1+r}}+\frac{e^{-\frac{2 \gamma}{\alpha(\theta-1)}}}{2} \frac{\alpha(1-\alpha)(\theta-1)}{\theta \alpha+1-\alpha}}}
$$

which equals the neoclassical benchmark when $\theta=1$.

\section{A.4 Steady state welfare}

For a household with income $Y_{i}$ at time $t$ given optimal choices, the maximized values are:

$$
\begin{aligned}
& U_{t}\left(Y_{i}, \text { rent }\right)=\alpha^{\alpha}(1-\alpha)^{1-\alpha}(1+r)^{1-\alpha} \frac{Y_{i}}{R_{t}^{\alpha}} \\
& U_{t}\left(Y_{i}, \text { own }\right)=\left(\frac{\theta \alpha}{\theta \alpha+1-\alpha}\right)^{\theta \alpha}\left(\frac{1-\alpha}{\theta \alpha+1-\alpha}\right)^{1-\alpha}(1+r)^{1-\alpha} \frac{Y_{i}^{\theta \alpha+1-\alpha}}{\left(P_{t}-P_{t+1} \frac{1-\delta}{1+r}\right)^{\theta \alpha}}
\end{aligned}
$$

Per Proposition 4. from the old steady state to the new steady state, there are those who stay renters, those who stay owners and those who switch from owner to renter (since homeownership rate goes down). Their log utility changes are characterized by:

$$
\begin{aligned}
\log U_{\tau}\left(Y_{i}, \text { rent }\right)-\log U_{t}\left(Y_{i}, \text { rent }\right) & =-\alpha\left(\log R_{\tau}-\log R_{t}\right) \\
\log U_{\tau}\left(Y_{i}, \text { rent }\right)-\log U_{t}\left(Y_{i}, \text { own }\right) & =-\alpha\left(\log R_{\tau}-\log R_{t}\right)-(\theta-1) \alpha\left(\log Y_{i}-\log \tilde{Y}_{t}\right) \\
\log U_{\tau}\left(Y_{i}, \text { own }\right)-\log U_{t}\left(Y_{i}, \text { own }\right) & =-\theta \alpha\left(\log \left(P_{\tau}-P_{\tau+1} \frac{1-\delta}{1+r}\right)-\log \left(P_{t}-P_{t+1} \frac{1-\delta}{1+r}\right)\right)
\end{aligned}
$$

From P/R increase, owner-owner welfare falls more than renter-renter. Owner-owner welfare always falls.

\section{B Housing and Tenure in CEX}

A key feature of the model that generates the results is the preference for ownership, which generates that ownership is a luxury while housing consumption expenditure itself has a close-to-linear Engel curve. To assess these features of the model, I first present evidence from survey data that indeed these two features characterize households' choice of housing tenure and expenditure.

I use the Consumer Expenditure Survey (CEX) for years 1984-2016. Data processing follows standard practices; see Henry de Frahan and Sakong (2020) for exactly how the variables were constructed. The consumption measure is the total flow measure, including imputed flow consumption values for both housing and vehicle for relevant owners. The housing consumption measure is rent for renters; for owners, I use rent-equivalent broad measure, which includes utilities. After-tax income is used for income.

The model describes Engel curves with respect to permanent income. To that end, I instrument for households' permanent income using their total consumption (Modigliani and Brumberg (1954); Friedman (1957); Battistin et al. (2009); Charles et al.(2009)). It is widely known that when using transitory income, housing expenditure is highly concave. Once instrumented for the permanent component, I find that the relationship becomes much closer to linear, confirming the Cobb-Douglas utility specification used in this paper.

Figure 5 plots the key relationships. Figures $5 \mathrm{a}$ and $5 \mathrm{c}$ plot homeownership status and housing consumption - rent for renters and imputed user cost for owners - against log total flow consumption. Each dot represents average values of each axis for a percentile of the consumption distribution, controlling for age, squared age and fixed effects for race, urban residence, Census regions and year of survey. These plots 
can be thought of as the reduced form plots in an IV specification where income is instrumented for using consumption.

Figures $5 \mathrm{~b}$ and $5 \mathrm{~d}$ repeat the same exercise again sorting by consumption, but with after-tax income on the X-axis. These plots are loose graphical representations of the IV regression of housing tenure and housing consumption on income, where income is instrumented for using consumption.

The first key feature is that homeownership is a luxury, as is widely known. What is notable is that even in the top of the permanent-income distribution, with the exception of the top 5\%, homeownership rate does not reach $100 \%$. Homeownership is increasing in income for most of the permanent-income distribution. This is important because what generates that homeownership is a luxury relies on preference for living in owner-occupied housing. An alternative and complementary mechanism for generating luxury homeownership is credit constraints on buying a home. What is notable here is that if the sole mechanism were borrowing constraints, we would expect the concavity to kick in lower in the permanent-income distribution. By contrast, the relationship is less concave and quite steep for a large segment of the distribution, suggesting that whatever mechanism that generates luxury homeownership operates throughout most of the permanent-income distribution.

Moving onto housing consumption, two features are notable. First is that log-on-log relationship between housing and total consumption is linear, and with a slope close to one. Second, the Engel curve for owners is shifted up relative to renters in a parallel shift. Both features are implications of the preference for homeownership and housing consumption as modeled in this paper.

The corresponding regression results in Table 4. First two columns present regressions of homeownership indicators on log consumption flow, with and without controls for age, year of study, urban status, Census region and race.

The next six columns regress housing consumption on log total consumption, a homeowner dummy and the interaction between the two. The first row is the Engel curve for renters, with a log-on-log slope fairly close to one. The second column confirms that the Engel curve slope is not different between renters and owners. Another important estimate is the coefficient on the homeowner dummy, which corresponds to the parallel upward shift in the Engel curve as in Figures $5 \mathrm{c}$ and $5 \mathrm{~d}$. With the exception of column 3 with no controls, there is $8-17 \%$ higher expenditure on housing for owners than for renters, conditional on total consumption.

Columns 7 and 8 replicate the full specification of column 6, but with after-tax income as the main Engel-curve regressor instead of consumption. Column 7 instruments for income using consumption, and is the main specification of the permanent-income regression. Column 8 presents the raw OLS regression of housing consumption on income. The coefficient on log income again finds an Engel curve close to one in column 7, at 0.809 for renters and 0.751 for owners. By contrast, using also the transitory-income variation in column 8, the slope is much smaller, recovering the familiar concavity in housing Engel curve when contemporary income is used instead of some measure of the permanent income. The last column is the first stage, regressing after-tax income on consumption.

Together, these results show three things. First, homeownership is a luxury, not just in the lower end of the permanent-income distribution, but throughout. Second, housing consumption has a log-on-log slope on total consumption close to one and hence has close to unit income elasticity when permanent income is used. Third, throughout the distribution, homeowners spend about 8-17\% more on housing than renters, conditional on permanent income. All three results are implications of the simple model, which are borne out robustly in consumption data. 


\section{Figure 5: Housing and Tenure in CEX}

These figures plot tenure choice and housing expenditure by tenure status using the Consumer Expenditure Survey (CEX) data, as bin scatters. Each dot represents the averages constructed from a percentile from the distribution of consumption expenditure. In the two plots on the left, the $\mathrm{X}$-axis is log consumption expenditure (i.e. the sorting variable itself); in the two plots on the right, the $\mathrm{X}$-axis is log after-tax income while still sorting using consumption expenditure. In the top two plots, the Y-axis is an indicator for homeownership as opposed to renting residence; in the bottom two plots, the Y-axis is the log of total housing consumption (rent for renters in blue and imputed user cost for owners in red). In constructing each bin scatter, each variable has been residualized by age, squared age and fixed effects for race, urban residence, Census region and year of survey.

(a) Tenure vs. consumption

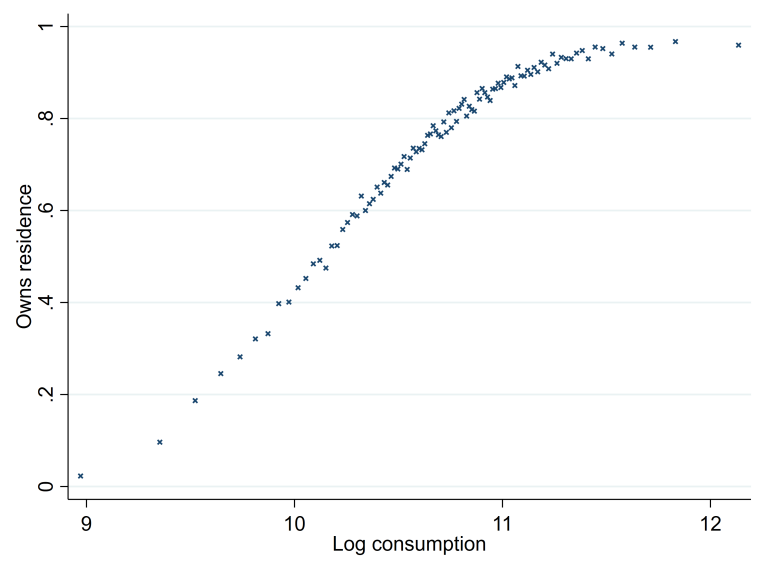

(c) Housing vs. consumption

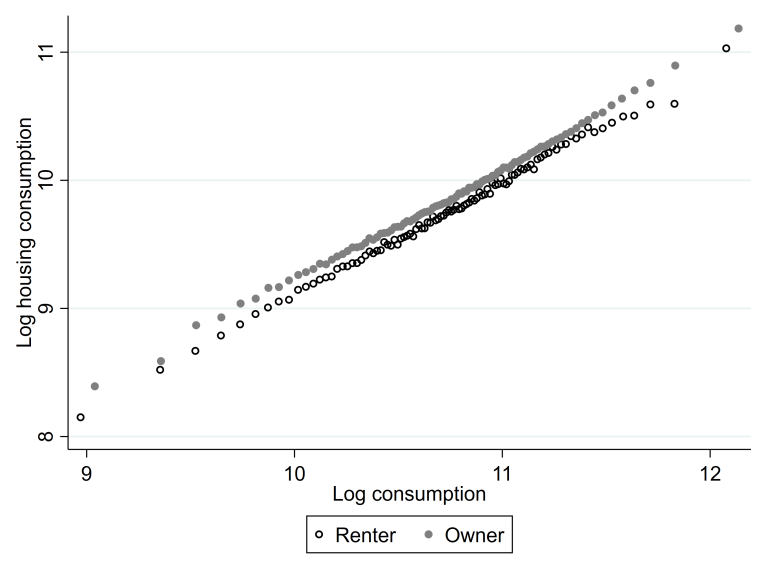

(b) Tenure vs. income (C sorted)

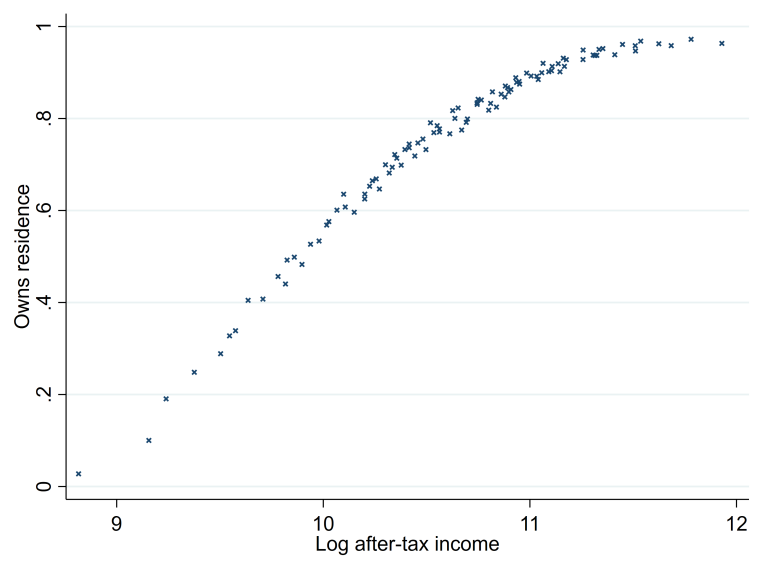

(d) Housing vs. income (C sorted)

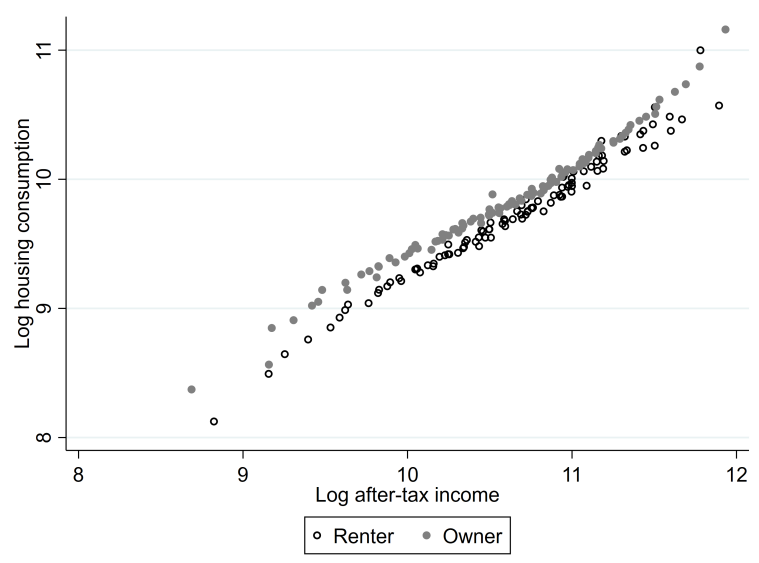




\section{Table 4: Housing Engel Curve (CEX)}

This table reports regression results from regressing both tenure status and housing cost on total consumption expenditure, from the Survey of Consumer Expenditure (CEX) data for 1984-2016. The first two columns regress an indicator for being a homeowner on log total consumption expenditure; the second column includes controls for age, squared age and fixed effects for year, urban residence, Census region and race. Columns (3) to (6) regresses log housing cost on log consumption expenditure, separately for owners and renters. Housing cost is rent for renters and imputed user cost for owners (see main text or Meyer and Sullivan (2017) for details). Column (6) includes the full set of controls. Column (7) and (8) replaces the set of regressors from log consumption expenditure to log after-tax income; column (7) instruments for the income regressors with the corresponding consumption-expenditure counterparts. The last column regresses after-tax income on consumption-expenditure, separately for renters and owners; it is the first-stage regression for the instrumental variables (IV) specification in column (7).

\begin{tabular}{|c|c|c|c|c|c|c|c|c|c|}
\hline & \multicolumn{2}{|c|}{ Owns home } & \multicolumn{6}{|c|}{ Log(housing) } & \multirow{2}{*}{$\frac{\log (\text { inc })}{(9)}$} \\
\hline & (1) & (2) & (3) & (4) & $(5)$ & (6) & (7) & (8) & \\
\hline Log(consumption) & $\begin{array}{c}0.322 \\
(0.002)\end{array}$ & $\begin{array}{c}0.361 \\
(0.002)\end{array}$ & $\begin{array}{c}0.857 \\
(0.004)\end{array}$ & $\begin{array}{c}0.850 \\
(0.004)\end{array}$ & $\begin{array}{c}0.846 \\
(0.004)\end{array}$ & $\begin{array}{c}0.887 \\
(0.004)\end{array}$ & & & $\begin{array}{l}1.093 \\
(0.008)\end{array}$ \\
\hline $\begin{array}{l}\text { Owns home } \times \\
\log (\text { consumption })\end{array}$ & & & $\begin{array}{c}0.020 \\
(0.004)\end{array}$ & $\begin{array}{l}-0.003 \\
(0.004)\end{array}$ & $\begin{array}{c}0.005 \\
(0.004)\end{array}$ & $\begin{array}{l}-0.002 \\
(0.004)\end{array}$ & & & $\begin{array}{c}0.087 \\
(0.010)\end{array}$ \\
\hline Owns home & & & $\begin{array}{l}-0.102 \\
(0.046)\end{array}$ & $\begin{array}{c}0.169 \\
(0.046)\end{array}$ & $\begin{array}{c}0.085 \\
(0.047)\end{array}$ & $\begin{array}{c}0.136 \\
(0.046)\end{array}$ & $\begin{array}{c}0.760 \\
(0.083)\end{array}$ & $\begin{array}{c}1.492 \\
(0.059)\end{array}$ & $\begin{array}{l}-0.961 \\
(0.106)\end{array}$ \\
\hline Log(income) & & & & & & & $\begin{array}{c}0.809 \\
(0.007)\end{array}$ & $\begin{array}{c}0.293 \\
(0.005)\end{array}$ & \\
\hline $\begin{array}{l}\text { Owns home } \times \\
\log (\text { income })\end{array}$ & & & & & & & $\begin{array}{l}-0.058 \\
(0.008)\end{array}$ & $\begin{array}{l}-0.093 \\
(0.006)\end{array}$ & \\
\hline Observations & 118836 & 114152 & 118827 & 118827 & 114143 & 114143 & 111198 & 127192 & 111206 \\
\hline $\begin{array}{l}\text { Adjusted } R^{2} \\
\text { IV }\end{array}$ & 0.195 & 0.337 & 0.786 & 0.797 & 0.798 & 0.817 & O & 0.464 & 0.488 \\
\hline 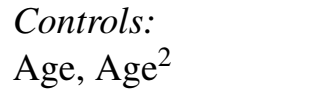 & & $\mathrm{O}$ & & & & $\mathrm{O}$ & $\mathrm{O}$ & $\mathrm{O}$ & $\mathrm{O}$ \\
\hline Year FE & & $\mathrm{O}$ & & & & $\mathrm{O}$ & $\mathrm{O}$ & $\mathrm{O}$ & $\mathrm{O}$ \\
\hline Urban/rural & & $\mathrm{O}$ & & $\mathrm{O}$ & & $\mathrm{O}$ & $\mathrm{O}$ & $\mathrm{O}$ & $\mathrm{O}$ \\
\hline Region FE & & $\mathrm{O}$ & & & $\mathrm{O}$ & $\mathrm{O}$ & $\mathrm{O}$ & $\mathrm{O}$ & $\mathrm{O}$ \\
\hline Race FE & & $\mathrm{O}$ & & & & $\mathrm{O}$ & $\mathrm{O}$ & $\mathrm{O}$ & $\mathrm{O}$ \\
\hline
\end{tabular}

